Cochrane Database of Systematic Reviews

\title{
Respiratory muscle training for cystic fibrosis (Review)
}

Hilton N, Solis-Moya A

Hilton N, Solis-Moya A.

Respiratory muscle training for cystic fibrosis.

Cochrane Database of Systematic Reviews 2018, Issue 5. Art. No.: CD006112.

DOI: 10.1002/14651858.CD006112.pub4. 
TABLE OF CONTENTS

HEADER 1

ABSTRACT

PLAIN LANGUAGE SUMMARY

SUMMARY OF FINDINGS

BACKGROUND

OBJECTIVES

METHODS

RESULTS

DISCUSSION

AUTHORS' CONCLUSIONS

ACKNOWLEDGEMENTS

REFERENCES

CHARACTERISTICS OF STUDIES

DATA AND ANALYSES

Analysis 1.1. Comparison 1 RMT (80\% of maximal effort) versus control, Outcome 1 Forced expiratory volume at one second (L).

Analysis 1.2. Comparison 1 RMT (80\% of maximal effort) versus control, Outcome 2 Forced vital capacity (L).

Analysis 1.3. Comparison 1 RMT (80\% of maximal effort) versus control, Outcome 3 Chronic Respiratory Disease Questionnaire (mastery).

Analysis 1.4. Comparison 1 RMT (80\% of maximal effort) versus control, Outcome 4 Chronic Respiratory Disease Questionnaire (emotion).

Analysis 2.1. Comparison 2 RMT (60\% of maximal effort) versus control, Outcome 1 Forced expiratory volume at one second (L).

Analysis 2.2. Comparison 2 RMT (60\% of maximal effort) versus control, Outcome 2 PImax $\left(\mathrm{cm} \mathrm{H}_{2} \mathrm{O}\right)$.

Analysis 3.1. Comparison 3 RMT (40\% of maximal effort) versus control, Outcome 1 Forced expiratory volume at one second (L).

Analysis 3.2. Comparison 3 RMT (40\% of maximal effort) versus control, Outcome 2 Forced expiratory volume at one second (\% predicted).

Analysis 3.3. Comparison 3 RMT (40\% of maximal effort) versus control, Outcome 3 Forced vital capacity (L).

Analysis 3.4. Comparison 3 RMT ( $40 \%$ of maximal effort) versus control, Outcome 4 Forced vital capacity (\% predicted).

Analysis 3.5. Comparison 3 RMT ( $40 \%$ of maximal effort) versus control, Outcome 5 Inspiratory muscle endurance (\% PImax). .

Analysis 4.1. Comparison 4 RMT (20\% of maximal effort) versus control, Outcome 1 Forced expiratory volume at one second (L).

Analysis 4.2. Comparison 4 RMT (20\% of maximal effort) versus control, Outcome 2 Forced vital capacity (L). 
[Intervention Review]

\section{Respiratory muscle training for cystic fibrosis}

Nathan Hilton ${ }^{1}$, Arturo Solis-Moya ${ }^{2}$

1Liverpool Heart and Chest Hospital NHS Foundation Trust, Liverpool, UK. 2 Servicio de Neumología, Hospital Nacional de Niños, San José, Costa Rica

Contact address: Nathan Hilton, Liverpool Heart and Chest Hospital NHS Foundation Trust, Thomas Drive, Liverpool, L14 3PE, UK. nathan.hilton@lhch.nhs.uk.

Editorial group: Cochrane Cystic Fibrosis and Genetic Disorders Group.

Publication status and date: New search for studies and content updated (no change to conclusions), published in Issue 5, 2018.

Citation: Hilton N, Solis-Moya A. Respiratory muscle training for cystic fibrosis. Cochrane Database of Systematic Reviews 2018 , Issue 5. Art. No.: CD006112. DOI: 10.1002/14651858.CD006112.pub4.

Copyright @ 2018 The Cochrane Collaboration. Published by John Wiley \& Sons, Ltd.

\section{A B S T R A C T}

\section{Background}

Cystic fibrosis is the most common autosomal recessive disease in white populations, and causes respiratory dysfunction in the majority of individuals. Numerous types of respiratory muscle training to improve respiratory function and health-related quality of life in people with cystic fibrosis have been reported in the literature. Hence a systematic review of the literature is needed to establish the effectiveness of respiratory muscle training (either inspiratory or expiratory muscle training) on clinical outcomes in cystic fibrosis. This is an update of a previously published review.

\section{Objectives}

To determine the effectiveness of respiratory muscle training on clinical outcomes in people with cystic fibrosis.

\section{Search methods}

We searched the Cochrane Cystic Fibrosis and Genetic Disorders Group Trials register comprising of references identified from comprehensive electronic database searches and handsearches of relevant journals and abstract books of conference proceedings.

Date of most recent search: 17 April 2018.

A hand search of the Journal of Cystic Fibrosis and Pediatric Pulmonology was performed, along with an electronic search of online trial databases up until 07 May 2018.

\section{Selection criteria}

Randomised controlled studies comparing respiratory muscle training with a control group in people with cystic fibrosis.

\section{Data collection and analysis}

Review authors independently selected articles for inclusion, evaluated the methodological quality of the studies, and extracted data. Additional information was sought from trial authors where necessary. The quality of the evidence was assessed using the GRADE system

\section{Main results}

Authors identified 19 studies, of which nine studies with 202 participants met the review's inclusion criteria. There was wide variation in the methodological and written quality of the included studies. Four of the nine included studies were published as abstracts only and lacking concise details, thus limiting the information available. Seven studies were parallel studies and two of a cross-over design. Respiratory muscle training interventions varied dramatically, with frequency, intensity and duration ranging from thrice weekly to twice daily, $20 \%$ to 
$80 \%$ of maximal effort, and 10 to 30 minutes, respectively. Participant numbers ranged from 11 to 39 participants in the included studies; five studies were in adults only and four in a combination of children and adults.

No significant improvement was reported in the primary outcome of pulmonary function (forced expiratory volume in one second and forced vital capacity) (very low-quality evidence). Although no change was reported in exercise capacity as assessed by the maximum rate of oxygen use, a $10 \%$ improvement in exercise duration was found when working at $60 \%$ of maximal effort in one study ( $n=20)$ (very lowquality evidence). In a further study $(n=18)$, when working at $80 \%$ of maximal effort, health-related quality of life improved in the mastery and emotion domains (very low-quality evidence). With regards to the review's secondary outcomes, one study $(n=11)$ found a significant change in intramural pressure, functional residual capacity and maximal inspiratory pressure following training (low-quality evidence). A further study $(n=22)$ reported that respiratory muscle endurance was significantly longer in the training group $(P<0.01)$. No studies reported on any other secondary outcomes. Meta-analyses could not be performed due to a lack of consistency and insufficient detail in reported outcome measures.

\section{Authors' conclusions}

There is insufficient evidence to suggest whether this intervention is beneficial or not. Healthcare practitioners should consider the use of respiratory muscle training on a case-by-case basis. Further research of reputable methodological quality is needed to determine the effectiveness of respiratory muscle training in people with cystic fibrosis. Researchers should consider the following clinical outcomes in future studies; respiratory muscle function, pulmonary function, exercise capacity, hospital admissions, and health-related quality of life. Sensory-perceptual changes, such as respiratory effort sensation (e.g. rating of perceived breathlessness) and peripheral effort sensation (e.g. rating of perceived exertion) may also help to elucidate mechanisms underpinning the effectiveness of respiratory muscle training.

\section{PLAIN LANGUAGE SUMMARY}

\section{Training the muscles that cause the chest to expand and contract in people with cystic fibrosis}

\section{Review question}

What are the effects of training muscles to expand and contract the chests of people with cystic fibrosis?

\section{Background}

Cystic fibrosis is the most common genetic disease in white populations and causes problems with the lungs in most people with the condition. Training the muscles that cause the chest to expand and contract may help to improve lung function and the quality of life for people with cystic fibrosis.

\section{Search date}

The evidence is current to: 17 April 2018.

\section{Study characteristics}

We searched for studies where people with cystic fibrosis were put into either a group for respiratory muscle training or a control group at random. We included nine studies with 202 people which used a wide variety of training methods and levels. In seven of the studies, the treatment group and the control group each only received either respiratory muscle training or a control treatment (one study had three groups in total: one receiving control treatment and two receiving different levels of training). In one study the participants received both types of treatment, but in a random order. Lastly, one study compared training with usual care. The studies lasted for a maximum of 12 weeks and all were quite small; the largest only had 29 people taking part. The studies included people with a range of ages over six years old, but most seemed to be adults. The studies reported a variety of outcomes. All reported some measure of respiratory muscle strength, and most reported at least one measure of lung function, however only three studies reported on quality of life.

\section{Key results}

Results could not be combined to answer the review question, because the studies either did not publish enough details or did not use the same standard measurements. No study found any difference in lung function after training, but one of the studies reported an improvement in exercise duration when training at $60 \%$ of maximal effort and a further study which trained participants at $80 \%$ of maximal effort reported some improvements in quality of life judgements. There was some evidence of an improvement in respiratory muscle function in one study.

Given this lack of information, a recommendation for or against respiratory muscle training cannot be made. Future studies should look to improve upon the methods of those previously conducted, and should report using standardised measurements.

\section{Quality of the evidence}

It was generally unclear how people were split into groups for treatment and whether this would have affected the results. Two studies stated that the people assessing the outcomes did not know which treatment those taking part had received, but this was unclear in other 
studies. Individuals dropped out of three of the studies for reasons which may be directly related to the treatment and therefore may introduce a risk of bias to the results. Other studies did not state how many people dropped out of them. We assessed the quality of the evidence and judged the evidence for lung function, exercise capacity and health-related quality of life to be very low quality, but the evidence for respiratory muscle function to be low quality. 


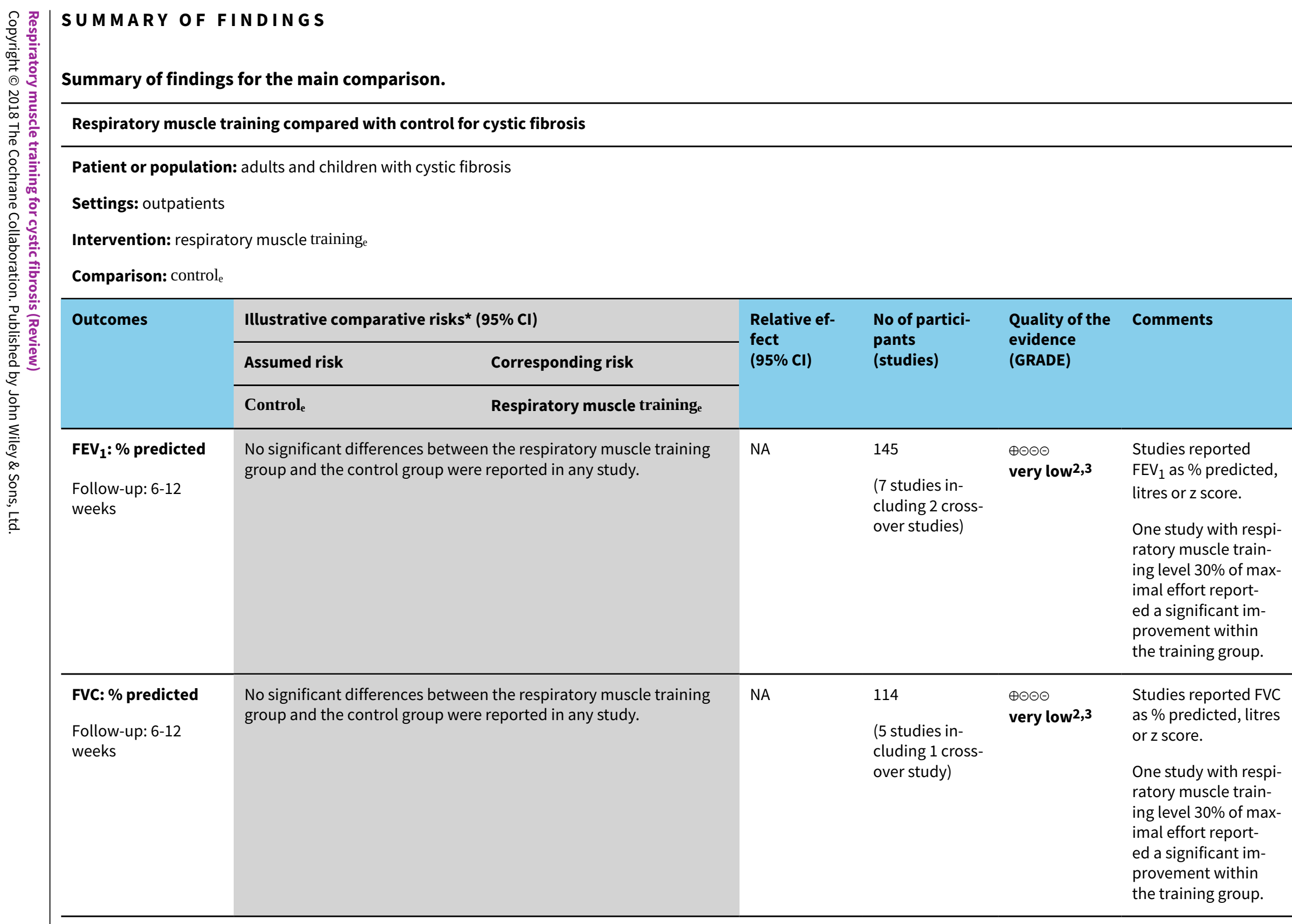




\begin{tabular}{|c|c|c|c|c|c|}
\hline $\begin{array}{l}\text { Exercise capacity: } \\
\mathrm{VO}_{2 \max }(\mathrm{mL} / \mathrm{kg} / \mathrm{min}) \\
\text { Follow-up: } 6-12 \\
\text { weeks }\end{array}$ & $\begin{array}{l}\text { No significant differences between the respiratory muscle training } \\
\text { group and the control group were reported in any study. }\end{array}$ & NA & $\begin{array}{l}54 \\
\text { ( } 3 \text { studies in- } \\
\text { cluding } 1 \text { cross- } \\
\text { over study) }\end{array}$ & $\begin{array}{l}\oplus \ominus \ominus \ominus \\
\text { very low } \mathbf{2 , 3}\end{array}$ & $\begin{array}{l}\text { One study with an } \\
\text { unspecified level of } \\
\text { resistance report- } \\
\text { ed a significant im- } \\
\text { provement within } \\
\text { the respiratory mus- } \\
\text { cle training group. }\end{array}$ \\
\hline $\begin{array}{l}\text { HRQoL: total score } \\
\text { Follow-up: } 8 \text { weeks }\end{array}$ & $\begin{array}{l}\text { Two studies reported no significant differences between the respira- } \\
\text { tory muscle training group and the control group. } \\
\text { One study reported significant improvements in the parameters of } \\
\text { mastery and emotion in the respiratory muscle training group com- } \\
\text { pared to the control group. }\end{array}$ & NA & $\begin{array}{l}69 \\
\text { ( } 3 \text { studies in- } \\
\text { cluding } 1 \text { cross- } \\
\text { over study) }\end{array}$ & $\begin{array}{l}\oplus \ominus \ominus \ominus \\
\text { very low } 2,3\end{array}$ & $\begin{array}{l}\text { Two studies used } \\
\text { the Chronic Respira- } \\
\text { tory Disease Ques- } \\
\text { tionnaire (CRDQ) and } \\
\text { one study used the } \\
\text { cystic fibrosis ques- } \\
\text { tionnaire (CFQ). }\end{array}$ \\
\hline $\begin{array}{l}\text { Respiratory muscle } \\
\text { function: maximal } \\
\text { inspiratory pressure } \\
(\mathrm{PI} \text { max }) \\
\text { Follow-up: 6-10 } \\
\text { weeks }\end{array}$ & $\begin{array}{l}\text { Significant improvements were observed in all respiratory muscle } \\
\text { training groups. } \\
\text { Two studies reported no significant differences between the respira- } \\
\text { tory muscle training group and the control group. }\end{array}$ & NA & $\begin{array}{l}51 \\
\text { ( } 3 \text { studies in- } \\
\text { cluding } 1 \text { cross- } \\
\text { over study) }\end{array}$ & $\begin{array}{l}\oplus \oplus \ominus \ominus \\
\text { low }^{2}\end{array}$ & \\
\hline $\begin{array}{l}\text { Respiratory muscle } \\
\text { function: inspiratory } \\
\text { capacity } \\
\text { Follow-up: NA }\end{array}$ & & & & NA & \\
\hline
\end{tabular}

*The basis for the assumed risk (e.g. the median control group risk across studies) is provided in footnotes. The corresponding risk (and its $95 \%$ confidence interval) is based on the assumed risk in the comparison group and the relative effect of the intervention (and its $95 \% \mathrm{Cl}$ ).

Cl: confidence interval; $\mathrm{FEV}_{1}$ : forced expiratory volume in 1 second; $\mathbf{F V C}$ : forced vital capacity; $\mathbf{H R Q} \mathbf{O L}$ : health related quality of life; $\mathbf{N A}$ : not applicable; $\mathrm{VO}_{2 \mathrm{max}}$ : maximal oxygen uptake.

GRADE Working Group grades of evidence

High quality: Further research is very unlikely to change our confidence in the estimate of effect.

Moderate quality: Further research is likely to have an important impact on our confidence in the estimate of effect and may change the estimate.

Low quality: Further research is very likely to have an important impact on our confidence in the estimate of effect and is likely to change the estimate.

Very low quality: We are very uncertain about the estimate.

1. The resistance level of the respiratory muscle training intervention was variable; three studies used $80 \%$ of maximal effort, one study used $60 \%$ of maximal effort, one study used $40 \%$ of maximal effort, one study used $30 \%$ of maximal effort and three studies did not specify the level of resistance. Control groups were also variable; cycle ergometer, $\mathrm{H}_{2} \mathrm{O}$, treatment as usual, standard chest physiotherapy, low resistance threshold loading device, no training or sham training. 
2. Downgraded twice due to serious risk of bias: the included studies lacked methodological detail relating to methods of randomisation, allocation concealment and blinding. Most of the studies were at high risk of bias due to lack of blinding, incomplete outcome data or selective reporting, or both.

3. Downgraded due to imprecision: studies included a small number of participants and numerical results were not available for some of the studies.

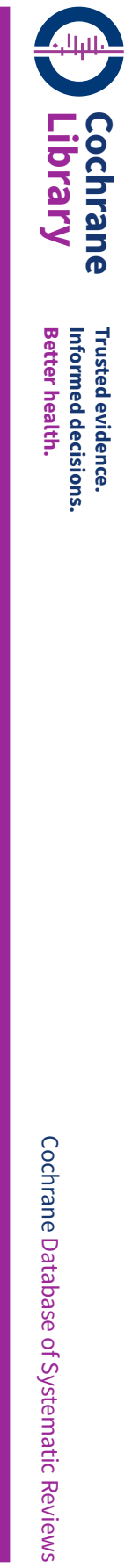




\section{B A C K G R O U N D}

\section{Description of the condition}

Cystic fibrosis (CF) is caused by a genetic mutation that disturbs the function of the $\mathrm{CF}$ transmembrane conductance regulator (CFTR) channel (Elborn 2016). Dysfunction of the CFTR channel reduces chloride secretion resulting in dehydrated and viscous secretions that become difficult to expectorate (Wine 1999). The pathological consequences of this mutation can impact function of the respiratory, reproductive, and digestive systems, as well as affecting temperature regulation and fluid balance (Wheatley 2011). Although the median predicted survival currently stands at 45.1 years (Carr 2016), the care and management of CF has improved dramatically over the last decade (De Boeck 2016).

Respiratory dysfunction accounts for approximately $80 \%$ to $95 \%$ of mortality (Lyczak 2002) and is a major cause of morbidity in CF. This is the manifestation of bacterial colonisation and chronic pulmonary infection that imposes structural lung damage, mostly bronchiectasis and small airway obstruction (Cantin 2015). Recurrent pulmonary infection results in the progressive deterioration of pulmonary function and eventually respiratory failure (Grasemann 2013). Other physiological factors such as inflammation, gas trapping and mucous plugging contribute towards further airway obstruction, thus reducing forced expiratory volumes and causing excessive dyspnoea (Kozlowska 2008). Co-morbidities such as thoracic kyphosis can exacerbate this, restricting lung expansion, decreasing lung volumes, and leading to an increased work of breathing (Aris 1998; Denton 1981).

Therapy in CF has evolved around preventing deterioration in pulmonary function which has led to a substantial increase in the life expectancy of those living with the condition. Thus, any intervention that improves pulmonary function and other associated health outcomes would be of great benefit in those with CF.

\section{Description of the intervention}

Respiratory muscle training (RMT) is a form of exercise training specifically targeting the muscles that drive expansion or contraction of the chest, or both. Training can stress the musculature of inspiration or expiration, or both, depending upon the type of training performed and the specification of the individual device. There are two main types of RMT, namely resistive training and normocapnic hyperpnoea. Resistive training can be performed using either flow-resistive loading or pressure-threshold loading, and requires the use of a portable hand-held device. Both devices typically involve a one-way valve mechanism, such that only the inspiratory or expiratory musculature can be trained at one given time. Flow-resistive loading involves breathing through a hole of small diameter (resistor), thus limiting airflow, increasing the work of breathing and challenging the respiratory musculature. The resistance (load) applied to the respiratory musculature can be adjusted according to the diameter of the hole, whereby reducing the diameter increases airflow limitation. Pressurethreshold training creates a similar physiological challenge, and involves breathing with sufficient force to overcome a springloaded valve to enable airflow. The resistance (load) is set at a proportion of maximal static inspiratory mouth pressure $\left(\mathrm{PI}_{\max }\right)$. Resistive training regimens vary in terms of the intensity (load), duration (sets, repetitions and time) and frequency (sessions per week), depending upon the desired physiological outcome i.e. muscular strength or endurance. Overall training volume can be altered using a combination of intensity, duration and frequency, and training can be either continuous or interval in nature. While resistive training can be performed under the supervision of a suitably qualified therapist, users may perform this independently.

Normocapnic hyperpnoea is a type of RMT that requires the individual to ventilate at a high proportion of their maximum voluntary ventilation (MVV) for a predetermined period of time. Complex rebreathing circuitry is required to perform this form of training and to minimise the risk of inducing hypercapnia. Unlike resistive training, normocapnic hyperpnoea trains both the inspiratory and expiratory musculature simultaneously. As the physiological challenge is derived from high ventilation, as opposed to high resistive load, the training load is determined by the rate of minute ventilation. For the same reason, normocapnic hyperpnoea targets muscular endurance as opposed to muscular strength.

\section{How the intervention might work}

It has been suggested that RMT may improve health-related quality of life, pulmonary function and exercise capacity in people with CF. Some studies have postulated that RMT may enhance the clearance of mucous from the lungs (Chatham 2004), which is considered to be a fundamental aspect in preventing pulmonary infection. Although RMT may be thought to improve pulmonary function, exercise tolerance and quality of life, the causal mechanisms remain unclear.

In those without CF, several potential mechanisms have been postulated that may also be comparable in those with CF. Perceptual changes have been found to occur following RMT, whereby a significant reduction in the perception of respiratory effort has been observed (Romer 2002). Numerous mechanisms have been hypothesised, including an improvement in the contractile properties of the inspiratory musculature, and a desensitising effect on the sensory input from the inspiratory muscles to the brain (El-Manshawi 1986; Revelette 1987; Wilson 1990). Significant reductions in the perception of peripheral effort have also been observed, attributed to a changes in acid-base balance and respiratory muscle blood flow (Caine 2000).

In CF, these mechanisms may also account for improvements in health-related quality of life, pulmonary function and exercise capacity that have been observed. As a combination of structural lung damage and physical deconditioning can increase the perception of respiratory (dyspnoea) and peripheral effort in people with CF, the need for this review is apparent.

\section{Why it is important to do this review}

Prior to the original version of this review (Houston 2008), there was no systematic review of the currently available evidence from randomised controlled trials (RCTs) or quasi-randomised controlled trials as to whether RMT is beneficial, nor on the optimal regime (i.e. the nature of the training load and specifics of the training protocol), for people with CF. The effect of RMT on improving health outcomes in CF remains unclear. Previous versions of this Cochrane Review were unable to conclude if this treatment is either beneficial or not, due to the apparent lack of clinical trials, particularly those of a high-quality; this version of the 
review is the latest update of the original review (Houston 2009; Houston 2013).

\section{O B JE C T IVES}

To determine the effectiveness of respiratory muscle training on clinical outcomes in people with cystic fibrosis.

\section{METHODS}

\section{Criteria for considering studies for this review}

\section{Types of studies}

Any parallel or cross-over randomised controlled trial (RCT) comparing RMT with a control group.

\section{Types of participants}

Any person with CF who has been diagnosed by sweat testing, genotyping or both. Participants were included irrespective of gender, age, or the presence of co-morbidities.

\section{Types of interventions}

Trials were considered for inclusion if the author(s) had compared RMT with a control group, such as a placebo (e.g. sham-training) or no intervention. RMT included either inspiratory or expiratory muscle training, or both, including resistive loading (flow-resistive or pressure threshold, or both) and normocapnic hyperpnoea training. Singing training interventions were excluded from this review. Studies that performed RMT in combination with any other form of physical exercise training were excluded from the review. Combining these interventions is the subject of another Cochrane Review (Radtke 2015).

\section{Types of outcome measures}

\section{Primary outcomes}

1. Pulmonary function

a. forced expiratory volume at one second $\left(\mathrm{FEV}_{1}\right)$

b. forced vital capacity (FVC)

2. Exercise capacity (measured by e.g. maximal oxygen uptake $\left(\mathrm{VO}_{2 \text { max }}\right)$, exercise duration, etc.)

3. Health-related quality of life (measured by e.g. Chronic Respiratory Disease Questionnaire (CRDQ) (Chauvin 2008), Cystic Fibrosis Questionnaire (CFQ) (Wenninger 2003), etc.)

\section{Secondary outcomes}

1. Respiratory muscle function
a. maximal inspiratory pressure $\left(\mathrm{PI}_{\max }\right)$
b. inspiratory capacity (IC)

2. Respiratory muscle strength and endurance (RME)

3. Frequency and duration of respiratory infections, hospitalisations

4. Adherence

5. Death or survival

6. Adverse effects (pneumothorax, musculoskeletal pains or injuries, others)

7. Costs

\section{Search methods for identification of studies}

Trial searches were not restricted by date, language, or publication status.

\section{Electronic searches}

We identified relevant studies from the Group's Cystic Fibrosis Trials Register using the term: inspiratory muscle training.

The Group's Cystic Fibrosis Trials Register, which is compiled from electronic searches of the Cochrane Central Register of Controlled Trials (CENTRAL) (updated each new issue of The Cochrane Library), weekly searches of MEDLINE, a search of Embase to 1995 and the prospective handsearching of two journals - Pediatric Pulmonology and the Journal of Cystic Fibrosis. Unpublished work is identified by searching the abstract books of four major cystic fibrosis conferences: the International Cystic Fibrosis Conference; the European Cystic Fibrosis Conference, the North American Cystic Fibrosis Conference and the Australia and New Zealand Cystic Fibrosis Conference. For full details of all searching activities for the register, please see the relevant sections of the Cystic Fibrosis and Genetic Disorders Group website.

Date of the last search of the Group's Cystic Fibrosis Trials Register: 17 April 2018.

We also performed separate searches of clinicaltrials.gov and the WHO ICTRP databases (Appendix 1; Appendix 2). Date of the last search: 07 May 2017.

For versions of the review up to and including 2014 the former author team also performed separate searches of the following databases: MEDLINE, Embase, CINAHL, AMED (Allied and Complementary Medicine), PEDro (The Physiotherapy Evidence Database), BIOSIS Previews, Science Direct and SCOPUS to 2013, using both the Cochrane RCT and Cystic Fibrosis search filters; and terms specific to the intervention (Appendix 3; Appendix 4; Appendix 5; Appendix 6). We also searched Current Controlled Trials and the UK National Research Register for ongoing and recently completed studies. These searches last run on the 01 August 2013 (Appendix 5; Appendix 6; Appendix 7).

\section{Searching other resources}

For the original review, we also contacted manufacturers and study investigators and checked reference lists of relevant literature.

\section{Data collection and analysis}

Where the text below describes "the authors", up to the 2018 update the original three authors (BH, NM and ASM) are referred to; thereafter "the authors" refers to $\mathrm{NH}$ and ASM.

\section{Selection of studies}

To identify potentially eligible studies, authors screened the titles and abstracts of each record retrieved from the search. They then obtained the full-text articles and inspected these independently for the review, including titles and abstracts that could not be rejected with certainty. If authors could not reach an agreement they would have resolved these issues by discussion and the involvement of another person if necessary. 


\section{Data extraction and management}

The review authors assessed the methodological quality of the selected studies and independently extracted data using a standardised data collection form based upon the recommendation in the Cochrane Handbook for Systematic Reviews of Interventions (Higgins 2011). Review authors entered all eligible studies into the Review Manager software (RevMan 2014). The authors did not need to resolve any disagreements.

\section{Assessment of risk of bias in included studies}

The authors used the Cochrane risk of bias tool to independently assess the study quality according to the following criteria: sequence generation, allocation concealment, blinding, incomplete outcome data, selective outcome reporting, and any other identified sources of bias (Higgins 2011). The external validity of each study was also considered, particularly the description of study participants (e.g. mean $\mathrm{FEV}_{1}$ ) and the study intervention (e.g. controlling inspiratory flow rate), as well as the reliability of reported outcomes (e.g. familiarity).

\section{Measures of treatment effect}

The authors graphically presented quantitative data for the outcomes listed in the inclusion criteria. For continuous outcomes (pulmonary function, exercise capacity, quality of life, respiratory muscle function, frequency and duration of respiratory infections, hospitalisations and costs) where they were able to obtain data, they calculated the mean differences (MD) and presented these with $95 \%$ confidence intervals (Cls). No analysable data were available for dichotomous outcomes; for future updates, if we are able to analyse dichotomous outcomes (adherence, survival and adverse effects), we plan to calculate the risk ratio (RR) and $95 \% \mathrm{Cls}$ for dichotomous outcomes.

\section{Unit of analysis issues}

Ideally when conducting a meta-analysis combining results from cross-over studies, the authors will use the inverse variance methods that are recommended by Elbourne (Elbourne 2002). However, if there are limited data available they plan to either use first-arm data only or treat the cross-over study as if it was of parallel design (assuming a correlation of zero as the most conservative estimate). Elbourne says that this approach produces conservative results as it does not take into account within-patient correlation (Elbourne 2002). Also each participant appears in both the treatment and control group, so the two groups are not independent. There are two cross-over studies included in the review (Asher 1983; Bieli 2017). Currently the authors have reported results from these studies narratively due to data limitations.

Where studies measured data longitudinally, the authors based the analysis on the results from the final time point. Methods are not yet available to carry out a meta-analysis of aggregate longitudinal data, where individual patient data (IPD) is not available.

\section{Dealing with missing data}

Where data were missing, the review authors attempted to contact the author(s) of the study to obtain the missing data. Only the available data were analysed (i.e. without imputing missing data).

\section{Assessment of heterogeneity}

The review authors would have conducted a meta-analysis and assessed heterogeneity if sufficient studies had been included and combined in the review. The authors planned to examine heterogeneity between comparable studies using a standard $\mathrm{Chi}^{2}$ test with the alpha level of significance set at $P<0.05$. Levels of heterogeneity would have been determined using the $\mathrm{I}^{2}$ statistic, whereby $\mathrm{I}^{2}$ greater than $50 \%$ was considered to be substantial heterogeneity (Deeks 2011).

\section{Assessment of reporting biases}

If sufficient data were available, the authors planned to explore potential publication bias by preparing a funnel plot. Where possible the authors compared the 'Methods' section of the full study report to the outcomes reported in the 'Results' section to identify any selective outcome reporting.

\section{Data synthesis}

The authors planned to pool the results of comparable groups of studies using the fixed-effect model and to calculate the relevant $95 \% \mathrm{Cls}$ if sufficient data were available.

\section{Subgroup analysis and investigation of heterogeneity}

The authors did not plan to perform any meta-analyses if there had been substantial and statistically significant heterogeneity. If the authors had been able to combine a sufficient number of included studies and had identified substantial heterogeneity (as defined above), the authors planned to explore this using the following subgroup analyses:

1. type of RMT (e.g. resistive loading or normocapnic hypopnea)

2. regimen of RMT (e.g. daily versus three times per week)

3. characteristics of study participants

a. age (up to 16 years versus older than 16 years)

b. gender

c. participants with poor respiratory muscle strength compared to those with preserved strength (e.g. determined by $\mathrm{PI}_{\max }$ )

d. participants with mild airflow obstruction compared to those with severe hyperinflation airflow obstruction (e.g. determined by $\mathrm{FEV}_{1}$ )

\section{4. definition of outcome measures}

\section{Sensitivity analysis}

If authors had been able to include and combine a sufficient number of studies, they would have performed sensitivity analyses based upon the methodological quality of the included studies, including allocation concealment, blinding of outcome assessments, and analyses performed on an intention-to-treat basis.

\section{Summary of findings tables}

In a post hoc change at the 2018 update, and in accordance with current Cochrane guidance, we have included a summary of findings table presenting results comparing respiratory muscle training (all intensities) versus control comparison. We have included the six outcomes which we consider to be the most clinically relevant. 
- $\mathrm{FEV}_{1} \%$ predicted

- FVC \% predicted

- $\mathrm{VO}_{2 \max }(\mathrm{mL} / \mathrm{kg} / \mathrm{min})$

- health-related quality of life (overall score)

- $\mathrm{PI}_{\max }$

- IC

We assess the quality of the evidence for each outcome using the GRADE approach. This approach is based on the risk of bias within the studies, relevance to our population of interest (indirectness), unexplained heterogeneity or inconsistency, imprecision of the results or high risk of publication bias. We downgraded the evidence once if the risk was serious and twice if the risk was deemed to be very serious.

\section{RESULTS}

\section{Description of studies}

\section{Results of the search}

The database searches identified 275 potentially eligible studies. The authors reviewed the abstracts of the studies and identified nine studies with a total of 202 participants for inclusion (Albinni 2004; Amelina 2006; Asher 1983; Bieli 2017; Chatham 1997; de Jong 2001; Enright 2004; Heward 2000; Sawyer 1993). Of these nine studies, four were published as abstracts only (Albinni 2004; Amelina 2006; Chatham 1997; Heward 2000). A further seven studies were excluded (Howard 2000; Irons 2012; Keens 1977; Patterson 2004; Santana-Sosa 2013; Sartori 2008; Vivodtzev 2013). Two studies are currently listed as 'Awaiting classification' until further details are available.

\section{Included studies}

A full comparison of the included studies can be found in the table (Characteristics of included studies).

\section{Study design}

All studies were RCTs. Of these, seven were of a parallel design (Albinni 2004; Amelina 2006; Chatham 1997; de Jong 2001; Enright 2004; Heward 2000; Sawyer 1993) and two studies had a crossover design (Asher 1983; Bieli 2017). One study utilised a threeway comparison between two different RMT interventions and control condition (Enright 2004). The duration of the intervention ranged from four (Asher 1983) to 12 weeks (Albinni 2004) and all outcomes were recorded at the end of the study period. All studies were relatively small with the number of participants ranging from 11 (Asher 1983) to 39 (Heward 2000). The studies were run in a number of different countries: USA (Heward 2000; Sawyer 1993); UK (Chatham 1997; Enright 2004); Netherlands (de Jong 2001); Switzerland (Bieli 2017); Canada (Asher 1983); Russia (Amelina 2006); and Austria (Albinni 2004). While most were single-centre studies (Albinni 2004; Amelina 2006; Bieli 2017; de Jong 2001; Enright 2004; Sawyer 1993), it was unclear if three studies were single or multicentre (Asher 1983; Chatham 1997; Heward 2000).

\section{Participants}

Participant characteristics were not consistently reported across studies. Two studies did not report the exact mean age or age range of participants, but indicated that they were adults (Amelina 2006; Chatham 1997). One further study explicitly stated that participants were adults and gave a mean age of 22.5 years (Heward 2000). Two studies reported age ranges that included children, adolescents and young adults; 6 to 18 years (Albinni 2004) and 9 to 24 years (Asher 1983). The remaining four studies gave more detailed information on participant age and indeed split according to treatment group (Bieli 2017; de Jong 2001; Enright 2004; Sawyer 1993). In each study, ages were similar between groups, but while the mean age for participants in two groups was in the early $20 \mathrm{~s}$ (de Jong 2001; Enright 2004), in one study it indicated that participants were children and adolescents (Sawyer 1993).

Six of the studies did not report on the gender split in participants (Albinni 2004; Amelina 2006; Asher 1983; Chatham 1997; Heward 2000; Sawyer 1993). Three studies reported on gender split by treatment group; in one study there were equal numbers of males and females (de Jong 2001) and in the remaining studies there were slightly more males than females (Bieli 2017; Enright 2004).

\section{Interventions}

There was great variation as to the method and level of training employed by the included studies. In the intervention group, three studies used $80 \%$ of maximal effort (Chatham 1997; Enright 2004; Heward 2000); one study used $60 \%$ of maximal effort (Sawyer 1993); one study used $40 \%$ of maximal effort (de Jong 2001); one study used 30\% of maximal effort (Amelina 2006) and three studies did not specify the level of resistance (Albinni 2004; Asher 1983; Bieli 2017). The frequency of training also varied. In two studies the frequency and duration of training was unclear (Chatham 1997; Heward 2000). Four studies used similar training regimens (Amelina 2006; Asher 1983; Bieli 2017; Sawyer 1993). Of these, two studies used a duration for each session of 10 to 15 minutes twice daily (Amelina 2006; Bieli 2017); one study used 15 minutes twice daily (Asher 1983) and one study used 30 minutes in total daily (Sawyer 1993). The remaining two studies used a regimen of training three times per week, but the duration of the sessions either varied (Enright 2004) or was not stated (Albinni 2004).

\section{Outcomes}

The outcome measures selected by the studies also varied greatly. All studies reported some measure of respiratory or inspiratory muscle strength. Most studies reported at least one measure of pulmonary function, principally $\mathrm{FEV}_{1}$ (Albinni 2004; Amelina 2006; Asher 1983; Bieli 2017; de Jong 2001; Enright 2004; Sawyer 1993) and FVC (Albinni 2004; Amelina 2006; Bieli 2017; de Jong 2001; Enright 2004). Six studies reported on exercise capacity (Albinni 2004; Amelina 2006; Asher 1983; Bieli 2017; de Jong 2001; Sawyer 1993), specifically maximal oxygen uptake $\left(\mathrm{VO}_{2 \mathrm{max}}\right)$ (Albinni 2004 ; Asher 1983; de Jong 2001) and exercise duration (Bieli 2017; Sawyer 1993). One study reported on exercise capacity but did not specify the outcome measure (Amelina 2006).

Three studies reported a measure of health-related quality of life using either the Chronic Respiratory Disease Questionnaire (CRDQ) (Chatham 1997; Enright 2004) or a combination of the Cystic Fibrosis Questionnaire (CFQ) and the Cystic Fibrosis Clinical Score (CFCS) (Bieli 2017). Other studies also reported on related outcomes such as perceived breathlessness (Albinni 2004; de Jong 2001) and fatigue (de Jong 2001). 


\section{Excluded studies}

A total of seven studies were excluded (see Characteristics of excluded studies). One study was excluded as the allocation was not randomised (Keens 1977), whereas two studies were excluded as they were not interventional trials (Patterson 2004; Sartori 2008). A further three studies were excluded as the intervention was not appropriate and could not be deemed a form of RMT (Howard 2000; Irons 2012; Vivodtzev 2013). Although one study used a form of RMT, it was combined with another form of exercise training, and was excluded as changes could not be attributed to RMT alone (Santana-Sosa 2013).

\section{Studies awaiting classification}

There are two studies currently listed as 'awaiting classification', both of which are currently published as abstracts only (Giacomodonato 2015; Ozaydin 2010).

\section{Study design}

Two studies stated that participants were randomised to either the control or intervention group, but gave no further details regarding study design (Giacomodonato 2015; Ozaydin 2010).

\section{Participants}

One study included 10 participants with CF aged between 21 and 40 years; there were six males and four females (Giacomodonato 2015). The second study included 28 participants with CF with a mean (SD) age 13.18 (3.65) years and a mean (SD) baseline value for FEV $_{1} \%$ predicted of $89.51 \%$ (19.47) (Ozaydin 2010).

\section{Interventions}

The Giacomodonato study allocated participants to either RME training with normocapnic hyperpnoea or standard chest physiotherapy (Giacomodonato 2015). Participants in the intervention group were asked to maintain $70 \%$ of $12 \mathrm{~s}$ maximum voluntary ventilation (MVV) until this could not be sustained, for 15 minutes daily over eight weeks.

Ozaydin allocated 14 participants to IMT training using a threshold loading device at $30 \%$ to $80 \%$ maximal inspiratory pressure (MIP) and 14 participants to sham training at 10\% MIP, for 20 minutes on five days per week (Ozaydin 2010).

\section{Outcomes}

One study stated that it had measured RME, six minute walk test (6MWT) distance, health-related quality of life (using the CFQ) and lung function (FVC, $\mathrm{FEV}_{1}$, MIP, MEP) pre- and post-intervention. However, the abstract only reported 6MWT distance between the groups following the intervention and we await the full publication for further results (Giacomodonato 2015).

The second study also measured the 6MWT distance and pulmonary function; in addition the investigators measured peripheral muscle strength (hand grip, shoulder abductors, elbow flexors) (Ozaydin 2010).

\section{Risk of bias in included studies}

\section{Allocation \\ Generation of allocation sequence}

Although all nine of the studies state that they randomised their participants to the treatment groups, only one study indicated the method of allocation by stating that they employed the minimisation method (de Jong 2001). This study was graded as having a low risk of bias, whereas the remaining eight studies were graded as having an unclear risk of bias.

\section{Concealment of allocation sequence}

None of the included studies made specific reference as to how, or even whether, this was addressed. All studies were assessed as having an unclear risk of bias in relation to this criteria.

\section{Blinding \\ Performance bias}

All the included studies were graded as having a high risk of performance bias since in all studies there was a clear difference between the experimental and control training. This ranged from no details being provided for the control group (Asher 1983) and 'no training' (Albinni 2004; Enright 2004; Heward 2000), through to minimal training and "sham" training (Amelina 2006; Chatham 1997; de Jong 2001; Sawyer 1993) and standard chest physiotherapy (Bieli 2017). Although the methodological difficulties of blinding the participants to this type of intervention are acknowledged, this can be addressed in some cases (e.g. RMT versus sham) but not all (e.g. training versus no training).

\section{Dectection bias}

Two studies blinded the outcome assessors at the final data collection session, although they did not state whether this was the case at the initial assessment or if the same assessors were used (Enright 2004; Sawyer 1993). A third study reports that the observers were blinded, although it does not expand on the level of this (Asher 1983). The remaining six studies make no overt reference to any blinding of outcome assessors and are deemed a high risk of bias (Albinni 2004; Amelina 2006; Bieli 2017; Chatham 1997; de Jong 2001; Heward 2000).

\section{Incomplete outcome data}

Only one study referred to the intention-to-treat principle (Bieli 2017). The trial reported that six out of 22 participants withdrew from the study, of these four participants discontinued the study in the control period, suggesting that withdrawal was not directly linked to the intervention in these cases. However, participants that withdrew did have a tendency to be older with characteristics of more advanced lung disease (Bieli 2017). This study was judged to have a low risk of bias.

Three studies were judged to have a high risk of bias (Asher 1983; de Jong 2001; Sawyer 1993). In the Asher study, two participants did not perform one of the post-treatment outcome measures, due to expiration up to residual volume resulting in coughing and there are no details on the regimen of the control group (Asher 1983). In the de Jong study, one participant in the intervention group withdrew after experiencing earache at a training intensity equating to $40 \%$ $\mathrm{PI}_{\max }$ (de Jong 2001). In the Sawyer study, two participants did 
not complete their pulmonary function tests: one was due to an oversight on the part of the researchers; and the other did not complete the test. There is no indication as to which group these participants are from (Sawyer 1993).

The remaining five studies were judged to have an unclear risk of bias (Albinni 2004; Amelina 2006; Chatham 1997; Enright 2004; Heward 2000). Two studies gave limited information on withdrawals; in the Amelina study, one participant in the intervention group did not complete the trial (Amelina 2006) and in the Chatham study, three participants in the control group did not complete the trial (Chatham 1997). Neither of these two studies offered any explanation for these withdrawals; however, as they are both abstracts published in conference proceedings and that there are likely to be editorial constraints responsible for this. Furthermore, both trials failed to provide statistical data on their control groups, merely stating that there was no change in their outcomes; therefore they have been graded as having an unclear risk of bias. The remaining three trials do not provide any information with regards to participant withdrawals (Albinni 2004; Enright 2004; Heward 2000).

\section{Selective reporting}

One study reported on all outcome measures selected, although some health-related quality of life domains were unreported; nevertheless the study was deemed to have a low risk of selective reporting bias (Bieli 2017). One study reported that the investigators carried out post-training measures of pulmonary function but do not report the results (Heward 2000). It is acknowledged that this study is only published as an abstract; however, there is a potential risk of bias due to the limited reporting of their outcomes. Likewise for the study by Amelina, two outcomes (respiratory muscle strength and dyspnoea) are reported to have been analysed, but no data are provided for them (Amelina 2006). There was insufficient information provided by the other publications to make a judgement on the risk of bias due to selective reporting from six trials and have been judged to have an unclear risk of bias (Albinni 2004; Asher 1983; Chatham 1997; de Jong 2001; Enright 2004; Sawyer 1993).

\section{Other potential sources of bias}

All the included studies have been graded an unclear risk of bias as none provided sufficient information to arrive at a definitive conclusion.

\section{Effects of interventions}

\section{See: Summary of findings for the main comparison}

Due to the lack of studies using comparable intensities of RMT or outcome measures, or both, we are unable to conduct metaanalyses at this time. All outcome measures were recorded at the end of the study period in each study.

\section{Primary outcomes}

\section{Pulmonary function}

Seven of the nine included studies reported some measure of pulmonary function; two included studies did not report on this outcome (Chatham 1997; Heward 2000). The quality of the evidence was judged to be very low (Summary of findings for the main comparison).

\section{a. $\mathrm{FEV}_{1}$}

Seven studies reported $\mathrm{FEV}_{1}$ in either litres (L) (Albinni 2004; de Jong 2001; Enright 2004; Sawyer 1993), \% predicted (Amelina 2006; Asher 1983; de Jong 2001) or using the $z$ score (Bieli 2017). We judged the quality of the evidence to be very low (Summary of findings for the main comparison).

One study reported $\mathrm{FEV}_{1}$ (L) at less than two months (de Jong 2001) and three studies reported at two to six months (Amelina 2006; Enright 2004; Sawyer 1993). There was no significant difference $(P>0.05)$ between groups in terms of $\mathrm{FEV}_{1}$ measured in $\mathrm{L}$ in any study irrespective of working at 80\% (Enright 2004), 60\% (Sawyer 1993), $40 \%$ (de Jong 2001) or 20\% (Enright 2004) of maximal effort (Analysis 1.1; Analysis 2.1; Analysis 3.1; Analysis 4.1). One study reported data for analysis for $\mathrm{FEV}_{1} \%$ predicted at $40 \%$ of maximal capacity (de Jong 2001); again no statistically significant differences were found between treatment groups (Analysis 3.2). A further study comparing $30 \%$ of maximal capacity to control reported on $\mathrm{FEV}_{1} \%$ predicted but only presented within-group changes (Amelina 2006). One cross-over study (unspecified level of resistance) reported the $\mathrm{FEV}_{1} \mathrm{z}$ score and found no significant difference $(P=0.436)$ between the treatment groups (Bieli 2017). Two studies (unspecified level of resistance) did not report any data, but state that there was no change in $\mathrm{FEV}_{1}$ in either the RMT or the control group (Albinni 2004; Asher 1983).

\section{b. FVC}

Six studies reported FVC in either L (Albinni 2004; de Jong 2001; Enright 2004), \% predicted (Amelina 2006; de Jong 2001) or using the $z$ score (Bieli 2017). We judged the quality of the evidence to be very low (Summary of findings for the main comparison).

Between-group comparisons did not reveal a significant difference $(\mathrm{P}>0.05)$ in FVC (L) irrespective of working at $80 \%$ (Enright 2004), 40\% (de Jong 2001) or 20\% (Enright 2004) of maximal effort (Analysis 1.2; Analysis 3.2; Analysis 4.2). This was also true for FVC (\% predicted) as reported by de Jong (de Jong 2001) (Analysis 3.4). One study reported data for analysis for FVC (\% predicted) at $40 \%$ of maximal capacity (de Jong 2001) and again no statistically significant differences were found between treatment groups (Analysis 3.4). A further study comparing 30\% of maximal capacity to control only reported within-group improvement in FVC (\% predicted) (Amelina 2006). One study did not report any data, but stated that there was no change in FVC in either the RMT or the control group (Albinni 2004). This was also the case for FVC (z score) as reported by Bieli (Bieli 2017).

\section{Exercise capacity}

Six studies reported some measure of exercise capacity (Albinni 2004; Amelina 2006; Asher 1983; Bieli 2017; de Jong 2001; Sawyer 1993); however, Amelina did not provide any units of measurement nor was there any explanation as to the method of assessment, but investigators did state that there was no improvement (Amelina 2006). The quality of the evidence was judged to be very low (Summary of findings for the main comparison).

\section{a. $\mathrm{VO}_{2 \max }$}

Three studies reported $\mathrm{VO}_{2 \max }$ as $\mathrm{mL} / \mathrm{kg} / \mathrm{min}^{-1}$, but not in a form that we could analyse (Albinni 2004; Asher 1983; de Jong 2001). 
One study reported no significant difference $(P=0.99)$ between groups when working at $40 \%$ of maximal effort (de Jong 2001). A further study reported mean (SD) $\mathrm{VO}_{\max }\left(\mathrm{mL} / \mathrm{kg} / \mathrm{min}^{-1}\right)$ at $31.6(5.0) \mathrm{mL} / \mathrm{kg} / \mathrm{min}^{-1}$ and 29.9 (6.4) $\mathrm{mL} / \mathrm{kg} / \mathrm{min}^{-1}$ pre and postintervention, with no significant difference (Asher 1983). A third study only reported within-group improvements, with no data to allow inclusion in our analysis (Albinni 2004).

\section{b. Exercise duration}

Two studies reported this outcome (Bieli 2017; Sawyer 1993). The cross-over study (unspecified level of resistance) did not provide data we could analyse, but reported no significant difference in exercise duration, measured using a constant workload cycling test, between groups $(P=0.169)$ (Bieli 2017). In the second study between-group comparisons found a $10 \%$ significant $(P<0.03)$ improvement when working at $60 \%$ of maximal effort (Sawyer 1993).

\section{Health-related quality of life}

Three studies reported a measure of health-related quality of life; two studies used the CRDQ (Enright 2004; Chatham 1997) and one study used the CFQ and the CFCS (Bieli 2017). The quality of the evidence was judged to be very low (Summary of findings for the main comparison).

The CRDQ evaluates four domains considered important to individuals with chronic airflow obstruction; dyspnoea, mastery, fatigue and emotion (Chauvin 2008). Chatham found a significant improvement $(P<0.01)$ between groups in the two parameters of mastery and emotion when working at $80 \%$ of maximal effort (Chatham 1997); however at the same level of effort, Enright found no significant differences between groups (Analysis 1.3; Analysis 1.4). Enright also found no significant difference between groups working at $20 \%$ of maximal effort (Enright 2004). Using the CFQ, Bieli found no difference in health-related quality of life between treatment groups (no specified level of resistance) (Bieli 2017).

Bieli also measured symptom severity using the CF clinical score (CFCS) which indicates overall symptom severity, but no significant difference was reported between groups at baseline or postintervention (Bieli 2017).

\section{Secondary outcomes}

\section{Respiratory muscle function}

Three studies reported $\mathrm{PI}_{\max }$ (Amelina 2006; Asher 1983; Sawyer 1993), but only one study provided data for analysis (Sawyer 1993). The quality of the evidence was judged to be low (Summary of findings for the main comparison).

\section{a. maximal inspiratory pressure $\left(\mathrm{PI}_{\max }\right)$}

After data analysis, Sawyer reported a significant difference in favour of the treatment group (60\% of maximal effort), MD 26.00 (95\% Cl 8.63 to 43.47 ) (Analysis 2.2). One study compared $30 \%$ resistance to control, but only reported within-group changes in $\mathrm{PI}_{\max }$ (Amelina 2006). Asher (unspecified level of resistance) utilised two inspiratory measures (prevailing intramural pressurefunctional residual capacity (Pim- $\mathrm{FRC}$ ) and $\mathrm{PI}_{\max }$ ) suggesting that one measurement technique was used but at two different lung volumes (Asher 1983). The study reported significant changes in both measures in the RMT group $(\mathrm{P}<0.025$ and $\mathrm{P}<0.05$ respectively). The investigators also reported that, for the Pim-FRC measure, only three participants registered an increase that was more than two standard deviations (2SD) from the control group; and for the $\mathrm{PI}_{\max }$ measure, two participants had an increase greater than two SD from the control values.

\section{b. inspiratory capacity (IC)}

No studies reported this outcome.

\section{Respiratory muscle strength and RME}

Five studies reported RME (Albinni 2004; Amelina 2006; Bieli 2017; Chatham 1997; de Jong 2001), but only three studies reported between-group comparisons (Albinni 2004; Bieli 2017; de Jong 2001).

One study presented values for mean (SD) and a $\mathrm{P}$ value which we were able to include in our analysis (de Jong 2001); results showed a statistically significant difference in favour of the RMT group, MD 12.00 (95\% $\mathrm{Cl} 0.55$ to 23.45) (Analysis 3.5). The remaining two studies did not provide data we could analyse. Albinni reported a significant improvement $(P=0.002)$ in RME in the training group (unspecified resistance) (Albinni 2004). Bieli also reported that RME was significantly longer in the training group $(P<0.01)$ (Bieli 2017).

One study reported a within-group improvement in the training group when working at $80 \%$ of maximal effort, but no data from the control group were reported (Chatham 1997). Likewise the final study reported a within-group improvement in the training group when working at $30 \%$ of maximal effort, but no data from the control group were reported (Amelina 2006).

\section{Frequency and duration of respiratory infections, hospitalisations}

No studies reported this outcome.

\section{Adherence to the IMT regimen}

No studies reported this outcome.

\section{Death or survival}

No studies reported this outcome.

\section{Adverse effects (pneumothorax, musculoskeletal pains or injuries, others)}

One study reported that one participant out of 16 experienced earache whilst performing IMT at $40 \%$ of maximal effort (de Jong 2001).

\section{Costs}

No studies reported this outcome.

\section{DISCUSSION}

\section{Summary of main results}

The main finding of this systematic review is that there is insufficient evidence to conclude if RMT has a positive effect on health outcomes in people with CF. This finding is based upon the small number of included studies $(n=9)$ and the small sample sizes used across the studies ( $n=11$ to 39). Of the nine included studies, only five (comprising 98 participants) were fully published studies (Asher 1983; Bieli 2017; de Jong 2001; Enright 2004; Sawyer 
1993) highlighting the need for further research. Abstracts from conference proceedings limit the amount of detailed data that are presented and thus the data that can be extracted.

Pulmonary function is routinely measured in clinical practice to monitor chest disease severity, specifically $\mathrm{FEV}_{1}$ and FVC. No differences were reported between groups in pulmonary function, including both FEV 1 and FVC, in any study. Only three of the studies included in the review reported that they assessed health-related quality of life (Bieli 2017; Chatham 1997; Enright 2004). Although no statistically significant difference was reported in two of the studies (Bieli 2017; Enright 2004), one study reported a significantly greater improvement in the two parameters of mastery and emotion in the treatment group $(\mathrm{P}<0.01)$ (Chatham 1997). Five of the nine studies reported some measure of exercise capacity (Albinni 2004; Asher 1983; Bieli 2017; de Jong 2001; Sawyer 1993). Of these, only one study reported a significant improvement with a $10 \%$ increase in exercise duration $(P<0.03)$ when working at $60 \%$ of maximal effort (Sawyer 1993).

Descriptive analysis of considered studies suggests that $\mathrm{PI}_{\max }$ and RME time are the measures that can best detect the effects of a RMT intervention. Although it is acknowledged that this is not supported by a meta-analysis of studies, they are the measures the included studies report as showing significant improvement within the RMT groups. Adverse events were consistently not reported by the studies, with only one making specific reference to this (de Jong 2001).

\section{Overall completeness and applicability of evidence}

Due to the life-limiting nature of CF, the clinical status of the participants recruited to studies in this population is of particular importance. The participants from the included studies have a mean age of approximately 18.5 years. With average life expectancy around 45.1 years (Carr 2016), the participants in these studies are effectively in middle age. It is possible that due to the progressive nature of the condition, the pulmonary function of the participants limited the effectiveness of RMT in comparison to a healthy population. There is an apparent under-use of assessing dyspnoea and exercise capacity following RMT which may limit the external validity of the research base. In healthy individuals, both an individual's perception of breathlessness and their maximal exercise capacity has found to improve following RMT (El-Manshawi 1986; Romer 2002).

\section{Quality of the evidence}

Overall, the methodological quality of the included studies was inconsistent and none addressed all aspects completely. A systematic review requires homogeneity between the included studies to allow firm conclusions to be drawn. Despite finding nine studies which met the inclusion criteria of this review, the variation in their methodologies and outcomes was such that no combined analyses could be made. These differences occurred in all the major aspects of the studies including the outcomes employed, the units of measurement for certain outcomes and the method and extent to which the clinical status of the participants was established or reported.

The execution of the included studies (randomisation and blinding) ranged from being fully acknowledged, considered and reported to either being merely stated as "randomised to the two groups" or not being mentioned. The external validity (with particular regard to the participant demographics) was explicit in only four of the studies (Bieli 2017; de Jong 2001; Enright 2004; Sawyer 1993). This aspect is of particular significance given that people who have CF are the target population. The nature of the disease means that two people of similar age, height and weight may have been affected by the condition differently and therefore may not "match" with regards to clinical status.

Although all studies state that they randomised their participants to the treatment groups, only one study indicated the method of allocation by stating that they employed the minimisation method (de Jong 2001). This study was graded as having a low risk of bias, whereas the remaining eight studies were graded as having an unclear risk of bias.

All the included studies were graded as having a high risk of performance bias, however studies are encouraged to specify more detail with regards to the training group. Although it may be difficult to blind the participants to which treatment arm they are randomised to, five studies made use of "sham" training for the control (Amelina 2006; Chatham 1997; de Jong 2001; Enright 2004; Sawyer 1993). Two studies blinded the outcome assessors at the final data collection session, whereas the majority of studies make no overt reference to any blinding. Out of the nine studies, none reported on all outcome measures thus suggesting a potential risk of bias. Two studies report withdrawals, but offer no explanation for these (Amelina 2006; Chatham 1997). Overall, all of the included studies have been graded an unclear risk of bias as none provided sufficient information to arrive at a definitive conclusion.

Following the GRADE assessments, pulmonary function, exercise capacity and health-related quality of life were deemed to be have very low-quality evidence, whereas evidence for respiratory muscle function was deemed to be of low quality (Summary of findings for the main comparison).

\section{Potential biases in the review process}

We are not aware of any potential biases in the review process.

\section{Agreements and disagreements with other studies or reviews}

Overally, the current systematic review supports previous versions of this review and continues to highlight the need for more research in this area, specifically studies of high methodological quality.

\section{AUTHORS' CONCLUSIONS}

\section{Implications for practice}

Given that there is insufficient evidence to suggest that this treatment is either beneficial or not, healthcare practitioners are advised to evaluate the use of respiratory muscle training (RMT) on a case-by-case basis when deciding whether or not to employ this form of exercise therapy in people with cystic fibrosis (CF).

\section{Implications for research}

Further research of reputable methodological quality is needed to determine the effectiveness of RMT in people with CF. Researchers are encouraged to consider the following clinical outcomes in future studies: 
- respiratory muscle function (e.g. maximal inspiratory pressure $(\mathrm{PI}$ max $)$;

- pulmonary function (e.g. forced expiratory volume in one second $\left(\mathrm{FEV}_{1}\right)$, forced vital capacity (FVC));

- exercise capacity (e.g. maximum rate of oxygen consumption $\left.\left(\mathrm{VO}_{2 \max }\right)\right)$;

- hospital admissions;

- time to next exacerbation; and

- health-related quality of life.

Sensory-perceptual changes, such as respiratory effort sensation (e.g. rating of perceived breathlessness) and peripheral effort sensation (e.g. rating of perceived exertion) may also help to elucidate mechanisms underpinning the effectiveness of RMT.

\section{A C K N OWLEDGEMENTS}

We acknowledge the valuable contribution to the protocol and review stage of this review from previous review authors (Professor Cees van der Schans, Brian Houston, Helen Handoll, Nicola Mills).

We thank Nikki Jahnke for her help and advice at both the protocol and review stage.

This project was supported by the National Institute for Health Research, via Cochrane Infrastructure funding to the Cochrane Cystic Fibrosis and Genetic Disorders Group. The views and opinions expressed therein are those of the authors and do not necessarily reflect those of the Systematic Reviews Programme, NIHR, NHS or the Department of Health. 


\section{RE F E R E N C E S}

\section{References to studies included in this review}

Albinni 2004 \{published data only\}

* Albinni S, Rath R, Renner S, Eichler I. Additional inspiratory muscle training intensifies the beneficial effects of cycle ergonometer training in patients with cystic fibrosis [abstract]. Journal of Cystic Fibrosis 2004;3(Suppl1):S63. [CFGD Register: PE148a]

Eichler I, Renner S, Albinni S, Nachbaur E, Rath R. Inspiratory muscle training adds beneficial effects to cycle ergometer training in patients with cystic fibrosis [abstract]. Pediatric Pulmonology 2005;40(Suppl 28):320. [CFGD Register: PE148b]

\section{Amelina 2006 \{published data only\}}

Amelina E, Cherniak A, Chikina S, Krasovsky S, Appaeva A. Inspiratory muscle training (IMT) in cystic fibrosis adults. European Respiratory Society Annual Congress. 2006; Vol. Sep 2-6; Munich, Germany:716s. [Abstract no: P4112; CFGD Register: PE177a]

Cherniak A, Amelina E, Krasovsky S, Nekludova G, Chikina S. The effect of high intensity inspiratory muscle training in adults with cystic fibrosis (CF). European Respiratory Journal 2007;30(Suppl 51):767s. [Abstract no: E4514; CENTRAL: 645383; CFGD Register: PE177b; CRS: 5500050000000531]

Asher 1983 \{published data only\}

* Asher MI, Pardy RL, Coates AL, Thomas E, Macklem PT. The effects of inspiratory muscle training in patients with cystic fibrosis. American Review of Respiratory Disease 1982;126(5):855-9. [CFGD Register: PE127b]

Asher MI, Pardy RL, Coates AL, Thomas E, Macklem PT. The effects of inspiratory muscle training in patients with cystic fibrosis. Australian and New Zealand Journal of Medicine (Annual Clinical and Scientific meeting for New Zealand Fellows and Advanced Trainees). 1983; Vol. 13:204. [CFGD Register: PE127a]

\section{Bieli 2017 \{published data only\}}

Bieli C, Summermatter S, Boutellier U, Moeller A. Respiratory muscle training improves respiratory muscle endurance but not exercise tolerance in children with cystic fibrosis. Pediatric Pulmonology 2017; Vol. 52, issue 3:331-6. [CENTRAL: 1262285; CFGD Register: PE236; CRS: 5500135000001736; DOI: 10.1002/ ppul.23647; PUBMED: 28114723]

\section{Chatham 1997 \{published data only\}}

Chatham K, Ionescu A, Davies C, Baldwin J, Enright S, Shale DJ. Through range computer generated inspiratory muscle training in cystic fibrosis [abstract]. Pediatric Pulmonology 1997;24 Suppl 14:299, Abstract no: 340. [CFGD Register: PE90]

\section{de Jong 2001 \{published data only\}}

de Jong W, van Aalderen WM, Kraan J, Koeter GH, van der Schans CP. Inspiratory muscle training in patients with cystic fibrosis. Respiratory medicine 2001;95(1):31-36. [CFGD Register: PE130]
Enright 2004 \{published data only\}

Enright S, Chatham K, lonescu AA, Shale DJ, Unnithan V. $A$ randomised double blind controlled trial of inspiratory muscle training in cystic fibrosis [abstract]. American Journal of Respiratory and Critical Care Medicine 2000;161(3 Suppl):A753. [CFGD Register: PE138a]

* Enright S, Chatham K, Ionescu AA, Unnithan VB, Shale DJ. Inspiratory muscle training improves lung function and exercise capacity in adults with cystic fibrosis. Chest 2004;126(2):405-11. [CFGD Register: PE138b]

\section{Heward 2000 \{published data only\}}

Campbell A, Enright S, Unnitham V. The effect of inspiratory muscle training on the measurement of resting energy expenditure in adult patients with cystic fibrosis and in health subjects [abstract]. European Respiratory Journal 2000;16(Suppl 31):153S. [CFGD Register: PE146b]

* Heward C, Enright S, Chatham K, Ionescu AA, Shale DJ, Unnitham $V$. The effect of inspiratory muscle training on lung volumes and diaphragm structure in cystic fibrosis patients and in healthy subjects [abstract]. European Respiratory Journal 2000;16(Suppl 31):153S. [CFGD Register: PE146a]

Withnall L, Enright S, Chatham K, Ionescu AA, Shale DJ, Unnitham $V$. The effect of inspiratory muscle training on exercise capacity and inspiratory muscle function in cystic fibrosis patients and in healthy subjects [abstract]. European Repiratory Journal 2000;16(Suppl31):330S. [CFGD Register: PE146c]

\section{Sawyer 1993 \{published data only\}}

Sawyer EH, Clanton TL. Improved pulmonary function and exercise tolerance with inspiratory muscle conditioning in children with cystic fibrosis. Chest 1993;104(5):1490-7. [CFGD Register: PE170]

\section{References to studies excluded from this review}

Howard 2000 \{published and unpublished data\}

Howard J, Bradley J, Hewitt O, Elborn S. The active cycle of breathing (ACBT) is a more effective method of airway clearance in cystic fibrosis (CF) patients than the test of incremental respiratory endurance (TIRE) [abstract]. Pediatric Pulomonology 2000;30 Suppl 20:304, Abstract no: 457. [CFGD Register: PE116]

\section{Irons 2012 \{published data only\}}

Irons JY, Kenny D, Chang AB. Let's sing out!: The effect of singing on quality of life and lung function of children and adolescents with cystic fibrosis. Www.anzctr.org.au/Trial/Registration/ TrialReview.aspx?ID=83944 2009. [CFGD Register: PE185a ; ]

* Irons JY, Kenny DT, McElrea M, Chang AB. Singing therapy for young people with cystic fibrosis : a randomized controlled pilot study. Music and Medicine 2012;4(3):136-45. [CFGD Register: PE185b; ] 
Keens 1977 \{published data only\}

Keens TG, Krastins IRB, Wannamaker E, Levison H, Crozier DN, Bryan AC. Ventilatory muscle endurance training in normal subjects and patients with cystic fibrosis. American Review of Respiratory Disease 1977;116(5):853-60.

\section{Patterson 2004 \{published data only\}}

Patterson JE, Bradley JM. Inspiratory muscle training in adult patients with cystic fibrosis: a randomised controlled trial to evaluate the efficacy of the test of incremental respiratory endurance (TIRE). Thorax 2004;59(Suppl II):ii13. [Abstract no: S36; CENTRAL: 518434; CFGD Register: PE236; CRS: 5500050000000533]

\section{Santana-Sosa 2013 \{published data only\}}

Santana-Sosa E, Gonzalez-Saiz L, Groeneveld IF, Villa-Asensi JR, Gomez de Aguero MIB, Fleck SJ, et al. Benefits of combining inspiratory muscle with 'whole muscle' training in children with cystic fibrosis: a randomised controlled trial. British Journal of Sports Medicine 2013 May 16 [Epub ahead of print]. [DOI: 10.1136/bjsports-2012-091892]

\section{Sartori 2008 \{published data only\}}

Sartori R, Barbi E, Poli F, Ronfani L, Marchetti F, Amadde O, et al. Respiratory training with a specific device in cystic fibrosis: a prospective study. Journal of Cystic Fibrosis 2008;7(4):313-9.

\section{Vivodtzev 2013 \{published data only\}}

Vivodtzev I, Decorte N, Wuyam B, Gonnet N, Durieu I, Levy P, et al. Benefits of neuromuscular electrical stimulation prior to endurance training in patients with cystic fibrosis and severe pulmonary dysfunction. Chest 2013;143(2):485-93.

\section{References to studies awaiting assessment}

\section{Giacomodonato 2015 \{published data only\}}

Giacomodonato B, Graziano L, Curzi M, Perelli T, De Sanctis S, Varchetta M, et al. Respiratory muscle endurance training with normocapnic hyperpnea in patients with cystic fibrosis. A randomized controlled study. Journal of Cystic Fibrosis 2015;14 Suppl 1:S41. [Abstract no.: WS21.10; CFGD Register: PE217]

\section{Ozaydin 2010 \{published data only\}}

Ozaydin Z, Savci S, Saglam M, Arikan H, Inal-Ince D, VardarYagli N, et al. Effects of inspiratory muscle training on functional capacity and muscle strength in patients with mild cystic fibrosis. European Respiratory Society Annual Congress; 2010 Sep 18-22; Barcelona, Spain. 2010. [Abstract no.: 5134; CFGD Register: PE235]

\section{Additional references}

\section{Aris 1998}

Aris RM, Renner JB, Winders AD, Buell HE, Riggs DB, Lester GE, Ontjes DA. Increased rate of fractures and severe kyphosis: sequelae of living into adulthood with cystic fibrosis. Annals of Internal Medicine 1998;128(3):186-93.

\section{Caine 2000}

Caine MP, McConnell AK. Development and evaluation of a pressure threshold inspiratory muscle trainer for use in the context of sports performance. Sports Engineering 2000;3(3):149-59.

\section{Cantin 2015}

Cantin AM, Hartl D, Konstan MW, Chmiel JF. Inflammation in cystic fibrosis lung disease: pathogensis and therapy. Journal of Cystic Fibrosis 2015;14(4):419-30.

\section{Carr 2016}

Carr S, Cosgriff R, Rajabzadeh-Heshejin. UK Cystic Fibrosis Registry 2015 Annual Data Report. Cystic Fibrosis Trust 2016.

\section{Chatham 2004}

Chatham K, lonescu AA, Nixon LS, Shale DJ. A short-term comparison of two methods of sputum expectoration in cystic fibrosis. European Respiratory Journal 2004;23(3):435-9.

\section{Chauvin 2008}

Chauvin A, Rupley L, Meyers K, Johnson K, Eason J. Outcomes in Cardiopulmonary Physical Therapy: Chronic Respiratory Disease Questionnaire (CRQ). Cardiopulmonary Physical Therapy Journal 2008;19(2):61-7.

\section{De Boeck 2016}

De Boeck K, Amaral MD. Progress in therapies for cystic fibrosis. The Lancet 2016;4(8):662-74.

\section{Deeks 2011}

Deeks JJ, Higgins JPT, Altman DG on behalf of the CSMG, editor(s). Chapter 9: Analysing data and undertaking metaanalysis. In: Higgins JPT, Green S editor(s). Cochrane Handbook for Systematic Reviews of Interventions Version 5.1.0 (updated March 2011). The Cochrane Collaboration, 2011. Available from cochrane-handbook.org.

\section{Denton 1981}

Denton JR, Tietjen R, Gaerlan PF. Thoracic kyphosis in cystic fibrosis. Clinical Orthopaedics and Related Research 1981;155:71-4.

\section{El-Manshawi 1986}

El-Manshawi A, Killian KJ, Summers E, Jones N. Breathlessness during exercise with and without resistive loading. Journal of Applied Physiology 1986;61(3):896-905.

\section{Elborn 2016}

Elborn JS. Cystic Fibrosis. The Lancet 2016;388(10059):2519-31.

\section{Elbourne 2002}

Elbourne DR, Altman DG, Higgins JPT, Curtin F, Worthington HV, Vail A. Meta-analyses involving cross-over trials: methodological issues. International Journal of Epidemiology 2002;31(1):140-9.

\section{Grasemann 2013}

Grasemann H, Ratjen F. Early lung disease in cystic fibrosis. The Lancet 2013;1(2):148-57. 


\section{Higgins 2011}

Editors: Julian PT Higgins and Douglas G Altman on behalf of the Cochrane Statistical Methods Group and the Cochrane Bias Methods Group. Chapter 8: Assessing risk of bias in included studies. Cochrane Handbook for Systematic Reviews of Interventions Version 5.1.0 [updated March 2011]. The Cochrane Collaboration, 2011. Available from www.cochranehandbook.org.

\section{Kozlowska 2008}

Kozlowska WJ, Bush A, Wade A, Aurora P, Carr SB, Castle RA, et al. Lung function from infancy to the preschool years after clinical diagnosis of cystic fibrosis. American Journal of Respiratory and Critical Care Medicine 2008;178(1):42-9.

\section{Lyczak 2002}

Lyczak JB, Cannon CL, Pier GB. Lung Infections Associated with Cystic Fibrosis. Clinical Microbiology Reviews 2002;15(2):194-222.

\section{Radtke 2015}

Radtke T, Nolan SJ, Hebestreit H, Kriemler S. Physical exercise training for cystic fibrosis. Cochrane Database of Systematic Reviews 2017, Issue 11. [DOI: 10.1002/14651858.CD002768.pub4]

\section{Revelette 1987}

Revelette WR, Wiley RL. Plasticity of the mechanism subserving inspiratory load perception. Journal of Applied Physiology 1987;62(5):1901-6.

\section{RevMan 2014 [Computer program]}

Nordic Cochrane Centre, The Cochrane Collaboration. Review Manager (RevMan). Version 5.3. Copenhagen: Nordic Cochrane Centre, The Cochrane Collaboration, 2014.

\section{Romer 2002}

Romer LE, McConnell AK, Jones DD. Effects of inspiratory muscle training on time-trial performance in trained cyclists. Journal of Sports Sciences 2002;29(97):547-62.

\section{CHARACTERISTICS OF STUDIES}

Characteristics of included studies [ordered by study ID]

\section{Wenninger 2003}

Wenninger K, Aussage P, Wahn U, Staab D. The revised GermanCystic Fibrosis Questionnaire: validation of a diseasespecific health-related quality of life instrument. Quality of Life Research 2003;12:77-85.

\section{Wheatley 2011}

Wheatley CM, Wilkins BW, Snyder EM. Exercise is medicine in cystic fibrosis. Exercise and Sport Sciences Reviews 2011;39(3):155-60.

\section{Wilson 1990}

Wilson RC, Jones PW. Influence of prior ventilatory experience on the estimation of breathlessness during exercise. Clinical Science 1990;78(2):149-53.

\section{Wine 1999}

Wine JJ. The genesis of cystic fibrosis lung disease. Journal of Clinical Investigation 1999;103(3):309-12.

\section{References to other published versions of this review Houston 2008}

Houston BW, van der Schans CP. Inspiratory muscle training for cystic fibrosis. Cochrane Database of Systematic Reviews 2008, Issue 4. [DOI: 10.1002/14651858.CD006112]

\section{Houston 2009}

Houston BW, Mills N, Solis-Moya A. Inspiratory muscle training for cystic fibrosis. Cochrane Database of Systematic Reviews 2009, Issue 3. [DOI: 10.1002/14651858.CD006112.pub2]

\section{Houston 2013}

Houston BW, Mills N, Solis-Moya A. Inspiratory muscle training for cystic fibrosis. Cochrane Database of Systematic Reviews 2013, Issue 11. [DOI: 10.1002/14651858.CD006112.pub3]

* Indicates the major publication for the study

\section{Albinni 2004}

$\begin{array}{ll}\text { Methods } & \text { Parallel design over } 12 \text { weeks. } \\ \text { Single-centre study in Austria. }\end{array}$

Participants

Total cohort: $n=27$.

Age range: 6 - 18 years.

Gender split: no information.

Interventions

RMT: no details; plus, cycle ergometer training 3 times per week.

Control: cycle ergometer training 3 times per week. 
Albinni 2004 (Continued)

Outcomes

$\mathrm{FEV}_{1}$, FVC, IMS, IME, MEC, perceived breathlessness, antibiotic use and ease or degree of expectoration.

Notes RME protocol: abstract only, no details given.

\section{Risk of bias}

\begin{tabular}{lll}
\hline Bias & Authors' judgement & Support for judgement \\
\hline $\begin{array}{l}\text { Random sequence genera- } \\
\text { tion (selection bias) }\end{array}$ & Unclear risk & Described as randomised, no details given. \\
\hline $\begin{array}{l}\text { Allocation concealment } \\
\text { (selection bias) }\end{array}$ & Unclear risk & Not described. \\
\hline $\begin{array}{l}\text { Blinding (performance } \\
\text { bias and detection bias) } \\
\text { All outcomes }\end{array}$ & High risk & Performance bias: clear difference between the interventions received. \\
\hline $\begin{array}{l}\text { Incomplete outcome data } \\
\text { (attrition bias) } \\
\text { All outcomes }\end{array}$ & Unclear risk & Dectection bias: No reference to any blinding. \\
\hline $\begin{array}{l}\text { Selective reporting (re- } \\
\text { porting bias) }\end{array}$ & Unclear risk & No information provided. Intention-to-treat: unclear. \\
\hline \begin{tabular}{l} 
Other bias \\
\hline
\end{tabular} & Unclear risk & Insufficient information available to arrive at a conclusion. \\
\hline
\end{tabular}

Amelina 2006

\begin{tabular}{ll}
\hline Methods & Parallel design over 6 weeks. \\
& Single-centre study in Russia. \\
\hline Participants & Total cohort: $\mathrm{n}=20$. Treatment group: $\mathrm{n}=10$; control group: $\mathrm{n}=10$. \\
& Age range was not stated, but all were adults. \\
& Gender split: no information. \\
& States no significant differences between groups in terms of gender, age, weight, height, pulmonary \\
& function. \\
\hline Interventions & Threshold loading device: \\
& Intervention group: $30 \%$ of $\mathrm{PI}$ max \\
& Control group: $7 \mathrm{~cm} \mathrm{H}_{2} \mathrm{O}$ \\
& Training regimen: 10 to 15 minutes twice daily for 6 weeks. \\
\hline Outcomes & FEV ${ }_{1}$, FVC, $\mathrm{PI}$ max $, \mathrm{IC}, \mathrm{RMS}, \mathrm{RME}$ and exercise capacity. \\
\hline Notes & Abstract only. \\
\hline
\end{tabular}

\section{Risk of bias}


Amelina 2006 (Continued)

\begin{tabular}{|c|c|c|}
\hline Bias & Authors' judgement & Support for judgement \\
\hline $\begin{array}{l}\text { Random sequence genera- } \\
\text { tion (selection bias) }\end{array}$ & Unclear risk & $\begin{array}{l}\text { The authors only state that the allocation was random without explaining the } \\
\text { process involved. }\end{array}$ \\
\hline $\begin{array}{l}\text { Allocation concealment } \\
\text { (selection bias) }\end{array}$ & Unclear risk & No details are provided. \\
\hline $\begin{array}{l}\text { Blinding (performance } \\
\text { bias and detection bias) } \\
\text { All outcomes }\end{array}$ & Unclear risk & $\begin{array}{l}\text { Performance bias: The comparison group are referred to only as the "control } \\
\text { group" with no mention of the intensity of the training used; i.e. if it was at } \\
\text { "sham" or sub-maximal levels. } \\
\text { Dectection bias: No reference to any blinding. }\end{array}$ \\
\hline $\begin{array}{l}\text { Incomplete outcome data } \\
\text { (attrition bias) } \\
\text { All outcomes }\end{array}$ & High risk & $\begin{array}{l}\text { No statistical data is presented for the control group. } \\
1 \text { participant from the intervention group did not complete the study; it was } \\
\text { not stated whether they were included or excluded from the final analysis. }\end{array}$ \\
\hline $\begin{array}{l}\text { Selective reporting (re- } \\
\text { porting bias) }\end{array}$ & High risk & $\begin{array}{l}2 \text { outcomes (respiratory muscle strength and dyspnoea) are mentioned as hav- } \\
\text { ing been analysed, but no data are provided for them. }\end{array}$ \\
\hline Other bias & Unclear risk & Insufficient information available to arrive at a conclusion. \\
\hline
\end{tabular}

\section{Asher 1983}

Methods Consecutive, self-control design over 8 weeks.

Study run in Canada, unclear if single- or multicentre.

\begin{tabular}{ll}
\hline Participants & Total cohort: $n=11$. \\
& Age range: $9-24$ years. \\
Gender split: no information.
\end{tabular}

Interventions $\quad$ RMT: inspiratory resistance, 15 minutes twice daily, no dosage.

Control: treatment at usual.

Outcomes IMS, $\mathrm{W}_{\max }, \mathrm{VO}_{2} \max , \mathrm{VE}$ and heart rate.

\section{Notes}

\section{Risk of bias}

\begin{tabular}{lll}
\hline Bias & Authors' judgement & Support for judgement \\
\hline $\begin{array}{l}\text { Random sequence genera- } \\
\text { tion (selection bias) }\end{array}$ & Unclear risk & Described as randomised, no details given. \\
\hline $\begin{array}{l}\text { Allocation concealment } \\
\text { (selection bias) }\end{array}$ & Unclear risk & Not described. \\
\hline $\begin{array}{l}\text { Blinding (performance } \\
\text { bias and detection bias) } \\
\text { All outcomes }\end{array}$ & High risk & $\begin{array}{l}\text { Performance bias: no details of the control training regimen are provided = } \\
\text { high risk. }\end{array}$ \\
\hline
\end{tabular}


Asher 1983 (Continued)

Dectection bias: observer blind = low risk .

$\begin{array}{ll}\begin{array}{l}\text { Incomplete outcome data } \\ \text { (attrition bias) }\end{array} & \text { High risk } \\ \text { All outcomes } & \begin{array}{l}\text { Max } \text { participants were unable to satisfactorily perform the outcome measure PI- } \\ \text { thors do not stipulate whether this occurred during the intervention or control } \\ \text { phase of the study. }\end{array} \\ \text { Intention-to-treat: unclear. }\end{array}$

\begin{tabular}{lll}
\hline $\begin{array}{l}\text { Selective reporting (re- } \\
\text { porting bias) }\end{array}$ & Unclear risk & Insufficient information available to arrive at a conclusion. \\
\hline Other bias & Unclear risk & Insufficient information available to arrive at a conclusion. \\
\hline
\end{tabular}

Bieli 2017

\begin{tabular}{ll}
\hline Methods & Randomised cross-over design. \\
& Single-centre study in Switzerland. \\
\hline Participants & Total cohort: $\mathrm{n}=22$. \\
& Age range: 9 - 18 years. \\
& Gender split: 10 male, 12 female. \\
\hline Interventions & $\begin{array}{l}\text { Intervention group: } 8 \text { weeks voluntary eucapnic hyperventilation, } 5 \text { self-selected days per week, } 2 \times \text { dai- } \\
\text { ly, } 5 \text { to } 10 \text { min per session. }\end{array}$ \\
\hline Control group: 8 weeks standardised chest physiotherapy. \\
\hline Rutcomes & score. \\
\hline Notes &
\end{tabular}

\section{Risk of bias}

\begin{tabular}{|c|c|c|}
\hline Bias & Authors' judgement & Support for judgement \\
\hline $\begin{array}{l}\text { Random sequence genera- } \\
\text { tion (selection bias) }\end{array}$ & Unclear risk & Described as randomised, no details given. \\
\hline $\begin{array}{l}\text { Allocation concealment } \\
\text { (selection bias) }\end{array}$ & Unclear risk & Not described. \\
\hline $\begin{array}{l}\text { Blinding (performance } \\
\text { bias and detection bias) } \\
\text { All outcomes }\end{array}$ & High risk & $\begin{array}{l}\text { Performance bias: the comparison was made to "standardised chest physio- } \\
\text { therapy" and would likely be aware of group allocation. } \\
\text { Dectection bias: No reference to any blinding. }\end{array}$ \\
\hline $\begin{array}{l}\text { Incomplete outcome data } \\
\text { (attrition bias) } \\
\text { All outcomes }\end{array}$ & Low risk & $\begin{array}{l}6 \text { participants ( } 27.3 \%) \text { discontinued the study ( } 4 \text { in the control period, } 2 \text { in the } \\
\text { intervention period). }\end{array}$ \\
\hline $\begin{array}{l}\text { Selective reporting (re- } \\
\text { porting bias) }\end{array}$ & High risk & $\begin{array}{l}\text { Some health-related quality of life domains are unreported. All other out- } \\
\text { comes are reported. }\end{array}$ \\
\hline
\end{tabular}


Bieli 2017 (Continued)

Other bias Unclear risk Insufficient information available to arrive at a conclusion.

Chatham 1997

Methods Parallel design over 8 weeks.

Study run in UK, not clear if single centre or 2 centres.

Participants Total cohort: $n=18$. Treatment group: $n=9$; control group: $n=9$.

All participants were adults, but no specific age details or information on gender split given.

Interventions Intervention: computer-generated through range RMT (TIRE) at $80 \%$ of individual capacity.

Control: threshold loading device at $30 \%$ of peak; the measure used is not named.

Outcomes Chronic Respiratory Disease Questionnaire ('mastery' and 'emotion' elements), RMS and RME.

$$
\text { Notes }
$$

\section{Risk of bias}

\begin{tabular}{|c|c|c|}
\hline Bias & Authors' judgement & Support for judgement \\
\hline $\begin{array}{l}\text { Random sequence genera- } \\
\text { tion (selection bias) }\end{array}$ & Unclear risk & Described as randomised, no details given. \\
\hline $\begin{array}{l}\text { Allocation concealment } \\
\text { (selection bias) }\end{array}$ & Unclear risk & Insufficient information available to arrive at a conclusion. \\
\hline \multirow[t]{2}{*}{$\begin{array}{l}\text { Blinding (performance } \\
\text { bias and detection bias) } \\
\text { All outcomes }\end{array}$} & Unclear risk & $\begin{array}{l}\text { Perfomance bias: the training intensities employed ( } 80 \% \text { and "threshold" } 30 \% \\
\text { training) could, potentially, have led the participants to know which group } \\
\text { they were in. }\end{array}$ \\
\hline & & Detection bias: no reference to any blinding. \\
\hline \multirow{2}{*}{$\begin{array}{l}\text { Incomplete outcome data } \\
\text { (attrition bias) } \\
\text { All outcomes }\end{array}$} & Unclear risk & $\begin{array}{l}\text { Insufficient information available to arrive at a conclusion; no statistical data } \\
\text { is presented for the control group. }\end{array}$ \\
\hline & & Intention-to-treat: 3 from 18 (17\%). \\
\hline $\begin{array}{l}\text { Selective reporting (re- } \\
\text { porting bias) }\end{array}$ & Unclear risk & $\begin{array}{l}\text { As this study (to date) is only published in abstract form it is unclear whether } \\
\text { the reported outcomes are all that were analysed. }\end{array}$ \\
\hline Other bias & Unclear risk & Insufficient information available to arrive at a conclusion. \\
\hline
\end{tabular}

\section{de Jong 2001}

\begin{tabular}{ll}
\hline Methods & Parallel design over 6 weeks. \\
& Single-centre study in the Netherlands.
\end{tabular}


Age range for total cohort 10 - 25 years. Treatment group: mean (SD) age $=17$ (5.2) years; control group: mean (SD) age $=19(5.5)$ years.

Gender split for total cohort: 8 male, 8 female. Treatment group: 4 male, 4 female; control: 4 male, 4 female.

RMT: threshold loading: 20 minutes a day, 5 days per week, at $40 \%$ of $\mathrm{PI}_{\max }$.
Control: threshold loading: 20 minutes a day, 5 days per week. at $10 \%$ of $\mathrm{PI}_{\max }$.

\begin{tabular}{|c|c|}
\hline Outcomes & $\begin{array}{l}\mathrm{FEV}_{1}, \mathrm{FVC}, \mathrm{W}_{\max }, \mathrm{VO}_{2} \text { max, } \mathrm{VE}_{\max }, \mathrm{RME} \text {, perceived breathlessness, general fatigue, physical fatigue, re- } \\
\text { duced activity score, reduced motivation score, mental fatigue and dyspnoea. }\end{array}$ \\
\hline
\end{tabular}

Notes

RME protocol: a commercially-available threshold-loading device (Threshold, Healthscan Products, Inc. USA) was used during an incremental loading procedure. In order to obtain pressures over $41 \mathrm{~cm}$ $\mathrm{H}_{2} \mathrm{O}$ an additional spring was inserted with a double-spring constant. Participants started inspiring from a threshold-loading device set at $30 \%$ of $\mathrm{PI}_{\max }$ for $2 \mathrm{~min}$. The threshold load was then increased every 2 min in increments of $10 \%$ of $\mathrm{PI}_{\max }$. The maximal load was defined as the highest load which could be reached and maintained for at least $1 \mathrm{~min}$ as a percentage of $\mathrm{PI}_{\max }$. The breathing pattern was not regulated.

\section{Risk of bias}

\begin{tabular}{|c|c|c|}
\hline Bias & Authors' judgement & Support for judgement \\
\hline $\begin{array}{l}\text { Random sequence genera- } \\
\text { tion (selection bias) }\end{array}$ & Low risk & $\begin{array}{l}\text { Participants were assigned to } 1 \text { of } 2 \text { groups by } 5 \text { factors: gender; age; } \mathrm{FEV}_{1} \text {; } \\
\text { FVC; and BMI using the minimization method. }\end{array}$ \\
\hline $\begin{array}{l}\text { Allocation concealment } \\
\text { (selection bias) }\end{array}$ & Unclear risk & Not described. \\
\hline $\begin{array}{l}\text { Blinding (performance } \\
\text { bias and detection bias) } \\
\text { All outcomes }\end{array}$ & High risk & $\begin{array}{l}\text { Performance bias: both training intensities were low; however, no attempt was } \\
\text { made to ascertain whether the participants knew if the received the training } \\
\text { intensity. } \\
\text { Detection bias: no reference to any blinding. }\end{array}$ \\
\hline $\begin{array}{l}\text { Incomplete outcome data } \\
\text { (attrition bias) } \\
\text { All outcomes }\end{array}$ & High risk & $\begin{array}{l}1 \text { participant in the intervention group was withdrawn due to earache experi- } \\
\text { enced whilst training at } 40 \% \text { of } \mathrm{PI}_{\max } \text {. } \\
\text { Intention-to-treat: } 1 \text { from } 15(6 \%) \text {. }\end{array}$ \\
\hline $\begin{array}{l}\text { Selective reporting (re- } \\
\text { porting bias) }\end{array}$ & Unclear risk & Insufficient information available to arrive at a conclusion. \\
\hline Other bias & Unclear risk & Insufficient information available to arrive at a conclusion. \\
\hline
\end{tabular}

\section{Enright 2004}

\begin{tabular}{ll}
\hline Methods & Parallel design over 8 weeks. \\
& Single centre in UK. \\
\hline Participants & Total cohort: $\mathrm{n}=29$. Treatment group 1: $\mathrm{n}=9$; treatment group 2: $\mathrm{n}=10 ;$ control group: $\mathrm{n}=10$. \\
& Age
\end{tabular}


Total cohort (all adults): mean (SD) age $=22(4.2)$ years.

Treatment group 1: mean (SD) age $=24.8(5.5)$ years .

Treatment group 2: mean (SD) age $=20$ (4.7) years; control group: mean (SD) age $=21.3(2.7)$ years .

Gender split

Total cohort: 16 male, 14 female.

Treatment group 1: 4 male, 6 female (according to table in paper).

Treatment group 2: 6 male, 4 female; control group: 6 male, 4 female.

All had similar age, height, weight and lung function at baseline.

Interventions

Intervention 1: RMT at $80 \%$ of "maximal inspiratory effort".

Intrevention 2: RMT at $20 \%$ of "maximal inspiratory effort".

Control: "No Training"

RMT is incremental maximal effort with progressively shorter rest periods, 3 times a week.

Outcomes

$\mathrm{FEV}_{1}$ (\% predicted), $\mathrm{FVC}$ (\% predicted), $\mathrm{PI}_{\max }, \mathrm{SPI}_{\max }$, heart rate, perceived exertion, dyspnoea and

Chronic Respiratory Disease Questionnaire.

Notes Sample size calculation undertaken such that study needed at least 9 participants in each group.

\section{Risk of bias}

\begin{tabular}{lll}
\hline Bias & Authors' judgement & Support for judgement \\
\hline $\begin{array}{l}\text { Random sequence genera- } \\
\text { tion (selection bias) }\end{array}$ & Unclear risk & No information provided. \\
\hline $\begin{array}{l}\text { Allocation concealment } \\
\text { (selection bias) }\end{array}$ & Unclear risk & No information provided. \\
\hline $\begin{array}{l}\text { Blinding (performance } \\
\text { bias and detection bias) }\end{array}$ & High risk & $\begin{array}{l}\text { Performance bias: the comparison was "no training" making it clear to the par- } \\
\text { ticipants which arm they were in. }\end{array}$ \\
$\begin{array}{l}\text { Dectection bias: outcome assessors at the final data collection session, al- } \\
\text { though they did not state whether this was the case at the initial assessment or } \\
\text { even if the same assessors carried out all the assessments. }\end{array}$ \\
$\begin{array}{l}\text { Incomplete outcome data } \\
\begin{array}{l}\text { (attrition bias) } \\
\text { All outcomes }\end{array}\end{array}$ & Unclear risk & $\begin{array}{l}\text { No mention is made of whether all participants completed the study or not. } \\
\text { Nor are there any statistical indications. }\end{array}$ \\
\hline $\begin{array}{l}\text { Selective reporting (re- } \\
\text { porting bias) }\end{array}$ & Unclear risk & \begin{tabular}{l} 
Intention-to-treat: unclear. \\
\hline $\begin{array}{l}\text { Other bias } \\
\text { Insufficient information available to arrive at a conclusion. }\end{array}$
\end{tabular} \\
\hline
\end{tabular}

Heward 2000

Methods Parallel design over 8 weeks.


Heward 2000 (Continued)

Not clear if single or multicentre, authors from UK and USA.

Participants Total cohort: $\mathrm{n}=39$ (19 with CF and 20 matched healthy controls). Treatment group CF: $\mathrm{n}=9$; control group CF: $\mathrm{n}=10$.

Age of CF adults: mean (SD) age $=22.5$ (3.5) years; age of healthy adults: mean (SD) age $=21.5(3.5)$ years.

Gender matched groups.

\begin{tabular}{ll}
\hline Interventions & Treatment: RMT at $80 \%$ of "maximal effort", no dosage stated. \\
& Control: no training. \\
\hline Outcomes & VC, TLC. \\
\hline Notes & $\begin{array}{l}\text { Only CF participants eligible for this review, } 10 \text { healthy adults in another RMT group and another con- } \\
\text { trol group. }\end{array}$ \\
& Abstracts only available.
\end{tabular}

\section{Risk of bias}

\begin{tabular}{|c|c|c|}
\hline Bias & Authors' judgement & Support for judgement \\
\hline $\begin{array}{l}\text { Random sequence genera- } \\
\text { tion (selection bias) }\end{array}$ & Unclear risk & Described as randomised, no details given. \\
\hline $\begin{array}{l}\text { Allocation concealment } \\
\text { (selection bias) }\end{array}$ & Unclear risk & Not described. \\
\hline $\begin{array}{l}\text { Blinding (performance } \\
\text { bias and detection bias) } \\
\text { All outcomes }\end{array}$ & High risk & $\begin{array}{l}\text { Performance bias: the comparison was "no training" making it clear to the par- } \\
\text { ticipants which arm they were in. } \\
\text { Detection bias: no reference to any blinding. }\end{array}$ \\
\hline $\begin{array}{l}\text { Incomplete outcome data } \\
\text { (attrition bias) } \\
\text { All outcomes }\end{array}$ & Unclear risk & $\begin{array}{l}\text { No information provided. } \\
\text { Intention-to-treat: unclear. }\end{array}$ \\
\hline $\begin{array}{l}\text { Selective reporting (re- } \\
\text { porting bias) }\end{array}$ & High risk & The post-training pulmonary function results were not presented. \\
\hline Other bias & Unclear risk & Insufficient information available to arrive at a conclusion. \\
\hline
\end{tabular}

\section{Sawyer 1993}

\begin{tabular}{ll}
\hline Methods & Parallel design over 10 weeks. \\
& Single-centre study in USA. \\
\hline Participants & Total cohort: $\mathrm{n}=20$; treatment group: $\mathrm{n}=10$; control group: $\mathrm{n}=10$. \\
& Treatment group: mean (SD) age $=11.46(2.45)$ years; control group: mean (SD) age $=9.76(2.57)$ years. \\
& No information on gender split. \\
\hline Interventions & Treatment: RMT at $60 \% \mathrm{PI}_{\max .}$
\end{tabular}


Sawyer 1993 (Continued)

Control: Sham IMT at $10 \% \mathrm{PI}_{\max }$.

Outcomes $\quad F_{1}$, VC, FRC, IC, RV, TLC, RV/TLC, FEV 1 FVC, MVV, exercise time.

Notes

Risk of bias

Bias Authors' judgement Support for judgement

Random sequence genera- Unclear risk Described as randomised, no details given.

tion (selection bias)

Allocation concealment $\quad$ Unclear risk $\quad$ Not described.
(selection bias)

\begin{tabular}{|c|c|c|}
\hline $\begin{array}{l}\text { Blinding (performance } \\
\text { bias and detection bias) } \\
\text { All outcomes }\end{array}$ & High risk & $\begin{array}{l}\text { Performance bias: there was a clear difference in the intensity of training al- } \\
\text { though no attempt was made to ascertain whether the participants in the } \\
\text { training groups knew if they received the training intensity. }\end{array}$ \\
\hline
\end{tabular}

All outcomes

Dectection bias: outcome assessors at the final data collection session, although they did not state whether this was the case at the initial assessment or even if the same assessors carried out all the assessments.

\begin{tabular}{ll}
\hline $\begin{array}{l}\text { Incomplete outcome data } \\
\text { (attrition bias) }\end{array}$ & High risk \\
All outcomes & $\begin{array}{l}2 \text { participants removed from analysis and the reasons for this were explained; } \\
\text { however, it is unclear which group(s) they were in. } \\
\text { Intention-to-treat: unclear. }\end{array}$
\end{tabular}

\begin{tabular}{lll}
\hline $\begin{array}{l}\text { Selective reporting (re- } \\
\text { porting bias) }\end{array}$ & Unclear risk & Insufficient information available to arrive at a conclusion. \\
\hline Other bias & Unclear risk & Insufficient information available to arrive at a conclusion. \\
\hline
\end{tabular}

$\%$ predicted: the volume of air exhaled expressed as a percentage of the expected volume based on the physical attributes of the individual BMI: body mass index

$\mathrm{FEV}_{1}$ : volume of air exhaled over the first second of a forced exhalation

$\mathrm{FEV}_{1} / \mathrm{FVC}=$ the ratio of $\mathrm{FEV}_{1}$ to $\mathrm{FVC}$

FRC: functional residual capacity

FVC: total volume of air forcibly exhaled

$\mathrm{FEF}_{25-75 \%}$ : forced expiratory flow $25-75 \%$

IC: inspiratory capacity

MEC: maximal exercise capacity

MIV: maximal inspiratory pressure

MVV: maximum voluntary ventilation

RME: respiratory muscle endurance

RMF: inspiratory muscle function

RMS: inspiratory muscle strength

RMT: inspiratory muscle training

$\mathrm{n}$ : number of participants

$\mathrm{PI}_{\text {max }}$ : maximal inspiratory pressure

RV: residual volume; i.e. the volume of air retained in the lungs following a maximal, voluntary exhalation (FVC)

RV/TLC: the ratio of residual volume to total lung capacity

SD: standard deviation

$\mathrm{SPI}_{\text {max }}$ : sustained maximal inspiratory pressure

TLC: total lung capacity; i.e. the calculated maximum potential volume of an individual's lungs

VC: the total volume of air that can be exhaled in any one breath

$\mathrm{VE}(\max )$ : maximal expired ventilation

$\mathrm{VO}_{2}$ max: maximal oxygen consumption

Respiratory muscle training for cystic fibrosis (Review) 
$\mathrm{W}_{\text {max }}$ : maximum work load

Characteristics of excluded studies [ordered by study ID]

\begin{tabular}{ll}
\hline Study & Reason for exclusion \\
\hline Howard 2000 & Inappropriate intervention - ACBT versus TIRE not RMT. \\
\hline Irons 2012 & Inappropriate intervention - singing training and not RMT. \\
\hline Keens 1977 & Study excluded as allocation not randomised. \\
\hline Patterson 2004 & Observational study, no randomisation. \\
\hline Santana-Sosa 2013 & $\begin{array}{l}\text { Although a form of IMT was used as an intervention it was used in combination with another ex- } \\
\text { ercise based intervention; therefore, it was impossible to attribute any observed changes to IMT } \\
\text { alone. }\end{array}$ \\
\hline Sartori 2008 & \begin{tabular}{l} 
Observational study, no randomisation. \\
\hline Vivodtzev 2013
\end{tabular} \\
\hline
\end{tabular}

ACBT: active cycle of breathing technique

RMT: respiratory muscle training

TIRE: test of incremental respiratory endurance

Characteristics of studies awaiting assessment [ordered by study ID]

Giacomodonato 2015

\begin{tabular}{ll}
\hline Methods & Parallel design over 8 weeks. \\
& Unclear if single- or multicentre study. \\
\hline
\end{tabular}

Participants Total cohort: $\mathrm{n}=10$. Unclear how may were allocated to intervention or control group.

Age range: 21 to 40 years.

Gender split: males, $n=6$; females, $n=4$.

Interventions Treatment: RME training at $70 \%$ of $12 \mathrm{~s} \mathrm{MVV} \mathrm{for} 15$ minutes daily.

Control: standard chest physiotherapy.

Outcomes RME, 6MWT distance, CFQ-R score, FVC, FEV1, MIP, MEP.

\section{Notes}

\section{Ozaydin 2010}

$\begin{array}{ll}\text { Methods } & \text { Parallel design over } 8 \text { weeks. } \\ \text { Unclear if single- or multicentre study. }\end{array}$

Participants

Total cohort: $\mathrm{n}=28$; treatment group: $\mathrm{n}=14$; control group: $\mathrm{n}=14$. 
Ozaydin 2010 (Continued)

Age, mean (SD): 13.18 (3.65) years.

$\mathrm{FEV}_{1} \%$ predicted, mean (SD): 89.51 (19.47) \% predicted.

No information on gender split.

Interventions $\quad$ Treatment: RMT at $30 \%$ to $80 \%$ of MIV for 20 minutes on 5 days per week ${ }^{-1}$.

Control: sham RMT at $10 \%$ of MIV for 20 minutes on 5 days per week ${ }^{-1}$.

Outcomes

Pulmonary function, 6MWT distance and peripheral muscle strength (hand grip, shoulder abductors, elbow flexors).

Notes

DATA AND ANALYSES

Comparison 1. RMT ( $80 \%$ of maximal effort) versus control

\begin{tabular}{|c|c|c|c|c|}
\hline Outcome or subgroup title & $\begin{array}{l}\text { No. of } \\
\text { studies }\end{array}$ & $\begin{array}{l}\text { No. of } \\
\text { partici- } \\
\text { pants }\end{array}$ & Statistical method & Effect size \\
\hline $\begin{array}{l}1 \text { Forced expiratory volume at } \\
\text { one second }(L)\end{array}$ & 1 & & Mean Difference (IV, Fixed, 95\% Cl) & Totals not selected \\
\hline 1.1 Two to six months & 1 & & Mean Difference (IV, Fixed, 95\% Cl) & $0.0[0.0,0.0]$ \\
\hline 2 Forced vital capacity (L) & 1 & & Mean Difference (IV, Fixed, 95\% Cl) & Totals not selected \\
\hline 2.1 Two to six months & 1 & & Mean Difference (IV, Fixed, 95\% Cl) & $0.0[0.0,0.0]$ \\
\hline $\begin{array}{l}3 \text { Chronic Respiratory Disease } \\
\text { Questionnaire (mastery) }\end{array}$ & 1 & & Mean Difference (IV, Fixed, 95\% Cl) & Totals not selected \\
\hline $\begin{array}{l}4 \text { Chronic Respiratory Disease } \\
\text { Questionnaire (emotion) }\end{array}$ & 1 & & Mean Difference (IV, Fixed, 95\% Cl) & Totals not selected \\
\hline
\end{tabular}

Analysis 1.1. Comparison 1 RMT ( $80 \%$ of maximal effort) versus control, Outcome 1 Forced expiratory volume at one second (L).

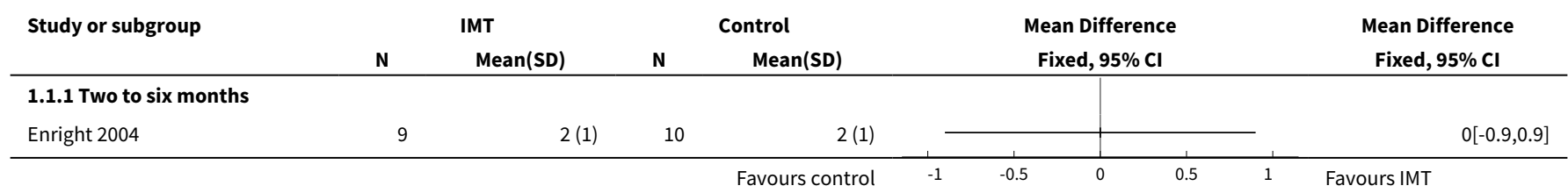


Analysis 1.2. Comparison 1 RMT ( $80 \%$ of maximal effort) versus control, Outcome 2 Forced vital capacity (L).

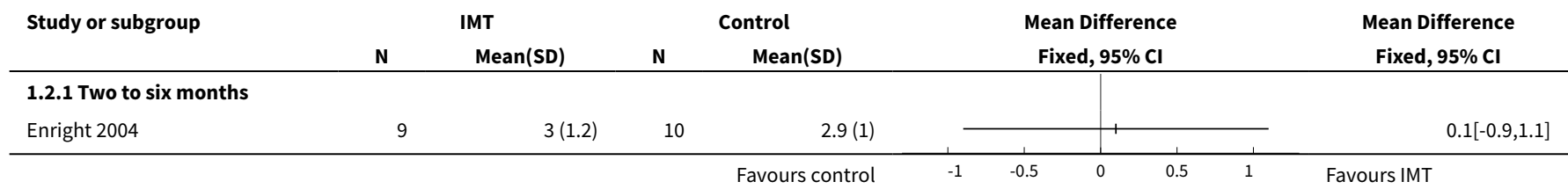

Analysis 1.3. Comparison 1 RMT ( $80 \%$ of maximal effort) versus control, Outcome 3 Chronic Respiratory Disease Questionnaire (mastery).

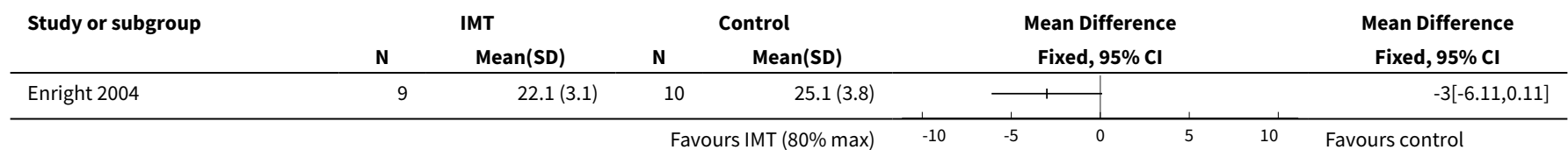

Analysis 1.4. Comparison 1 RMT ( $80 \%$ of maximal effort) versus control, Outcome 4 Chronic Respiratory Disease Questionnaire (emotion).

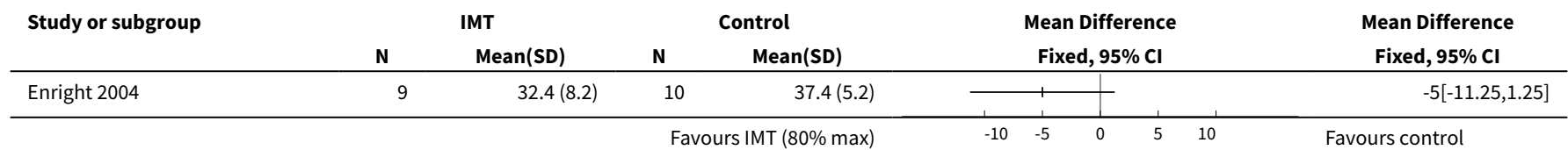

Comparison 2. RMT ( $60 \%$ of maximal effort) versus control

\begin{tabular}{lllll}
\hline Outcome or subgroup title & $\begin{array}{l}\text { No. of } \\
\text { studies }\end{array}$ & $\begin{array}{l}\text { No. of } \\
\text { partici- } \\
\text { pants }\end{array}$ & Statistical method & Effect size \\
\hline $\begin{array}{l}\text { f Forced expiratory volume at one sec- } \\
\text { ond (L) }\end{array}$ & 1 & Mean Difference (IV, Fixed, 95\% Cl) & Totals not selected \\
\hline $\begin{array}{llll}1.1 \text { Two to six months } \\
2 \text { PImax }\left(\mathrm{cm} \mathrm{H}_{2} \mathrm{O}\right)\end{array}$ & 1 & Mean Difference (IV, Fixed, 95\% Cl) & $0.0[0.0,0.0]$ \\
\hline 2.1 Two to six months & 1 & Mean Difference (IV, Fixed, 95\% Cl) & Totals not selected \\
\hline
\end{tabular}

Analysis 2.1. Comparison 2 RMT (60\% of maximal effort) versus control, Outcome 1 Forced expiratory volume at one second (L).

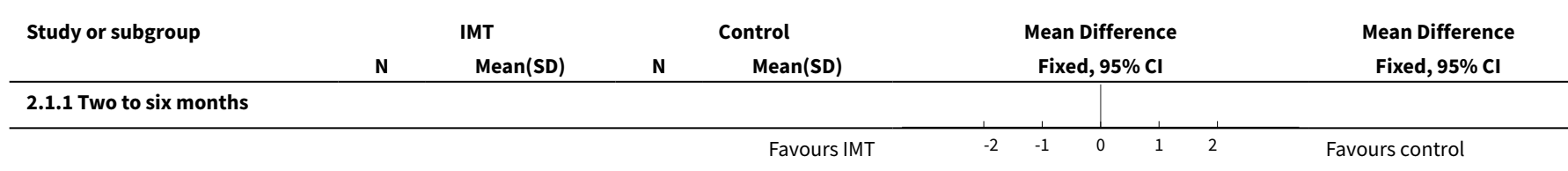




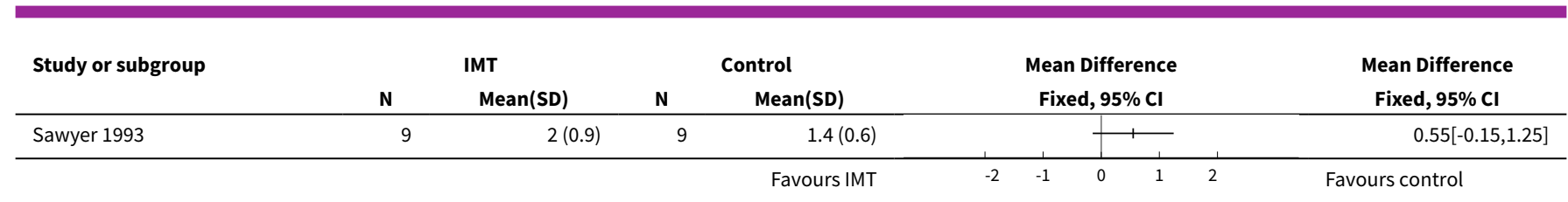

Analysis 2.2. Comparison 2 RMT ( $60 \%$ of maximal effort) versus control, Outcome 2 PImax $\left(\mathrm{cm} \mathrm{H}_{2} \mathrm{O}\right)$.

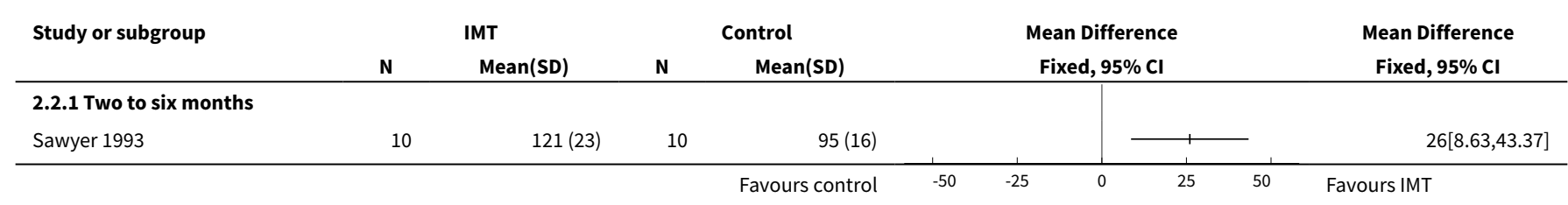

Comparison 3. RMT ( $40 \%$ of maximal effort) versus control

\begin{tabular}{|c|c|c|c|c|}
\hline Outcome or subgroup title & $\begin{array}{l}\text { No. of } \\
\text { studies }\end{array}$ & $\begin{array}{l}\text { No. of } \\
\text { partici- } \\
\text { pants }\end{array}$ & Statistical method & Effect size \\
\hline 1 Forced expiratory volume at one second (L) & 1 & & $\begin{array}{l}\text { Mean Difference (IV, Fixed, } \\
95 \% \mathrm{Cl} \text { ) }\end{array}$ & Totals not selected \\
\hline 1.1 Less than two months & 1 & & $\begin{array}{l}\text { Mean Difference (IV, Fixed, } \\
95 \% \mathrm{CI})\end{array}$ & $0.0[0.0,0.0]$ \\
\hline $\begin{array}{l}2 \text { Forced expiratory volume at one second ( } \% \\
\text { predicted) }\end{array}$ & 1 & & $\begin{array}{l}\text { Mean Difference (IV, Fixed, } \\
95 \% \mathrm{CI})\end{array}$ & Totals not selected \\
\hline 2.1 Less than two months & 1 & & $\begin{array}{l}\text { Mean Difference (IV, Fixed, } \\
95 \% \mathrm{CI})\end{array}$ & $0.0[0.0,0.0]$ \\
\hline 3 Forced vital capacity (L) & 1 & & $\begin{array}{l}\text { Mean Difference (IV, Fixed, } \\
95 \% \mathrm{CI})\end{array}$ & Totals not selected \\
\hline 3.1 Less than two months & 1 & & $\begin{array}{l}\text { Mean Difference (IV, Fixed, } \\
95 \% \mathrm{CI})\end{array}$ & $0.0[0.0,0.0]$ \\
\hline 4 Forced vital capacity (\% predicted) & 1 & & $\begin{array}{l}\text { Mean Difference (IV, Fixed, } \\
95 \% \mathrm{CI})\end{array}$ & Totals not selected \\
\hline 4.1 Less than two months & 1 & & $\begin{array}{l}\text { Mean Difference (IV, Fixed, } \\
95 \% \mathrm{CI})\end{array}$ & $0.0[0.0,0.0]$ \\
\hline 5 Inspiratory muscle endurance (\% PImax) & 1 & & $\begin{array}{l}\text { Mean Difference (IV, Fixed, } \\
95 \% \mathrm{CI})\end{array}$ & Totals not selected \\
\hline 5.1 Less than two months & 1 & & $\begin{array}{l}\text { Mean Difference (IV, Fixed, } \\
95 \% \mathrm{CI} \text { ) }\end{array}$ & $0.0[0.0,0.0]$ \\
\hline
\end{tabular}


Analysis 3.1. Comparison 3 RMT (40\% of maximal effort) versus control, Outcome 1 Forced expiratory volume at one second (L).

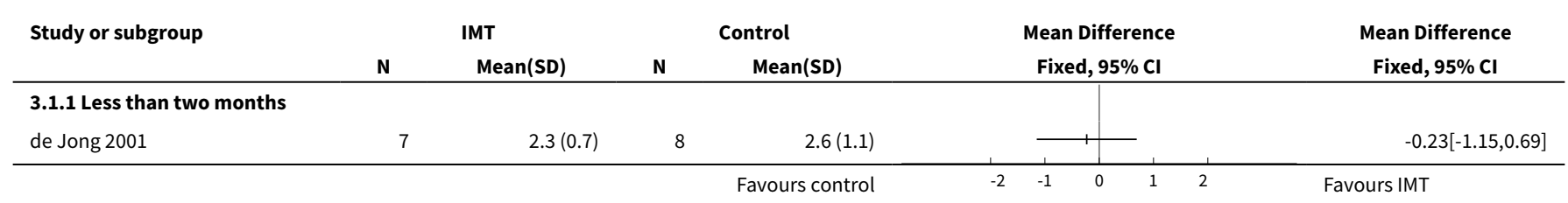

Analysis 3.2. Comparison 3 RMT (40\% of maximal effort) versus control, Outcome 2 Forced expiratory volume at one second (\% predicted).

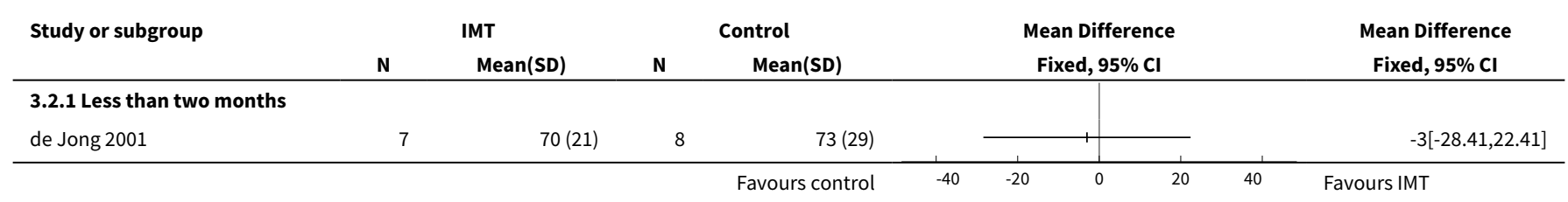

Analysis 3.3. Comparison 3 RMT (40\% of maximal effort) versus control, Outcome 3 Forced vital capacity (L).

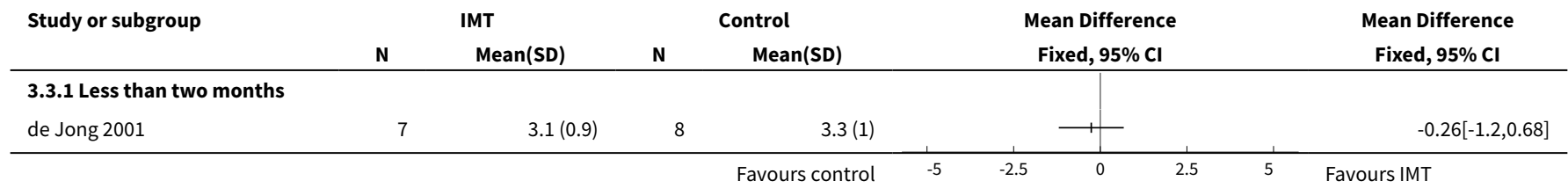

Analysis 3.4. Comparison 3 RMT (40\% of maximal effort) versus control, Outcome 4 Forced vital capacity (\% predicted).

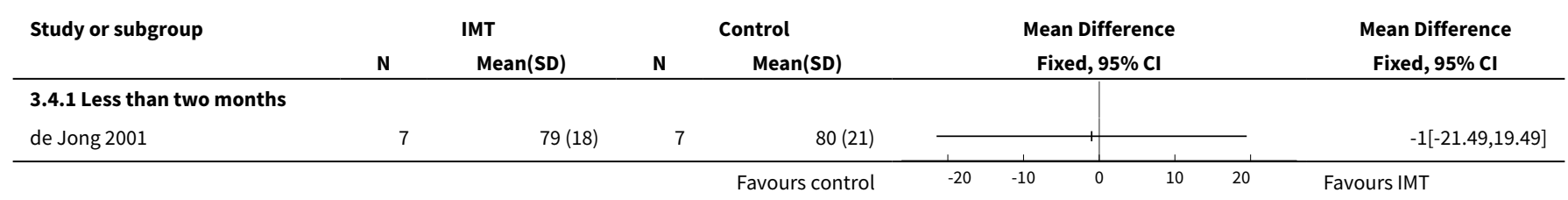

Analysis 3.5. Comparison 3 RMT (40\% of maximal effort) versus control, Outcome 5 Inspiratory muscle endurance (\% PImax).

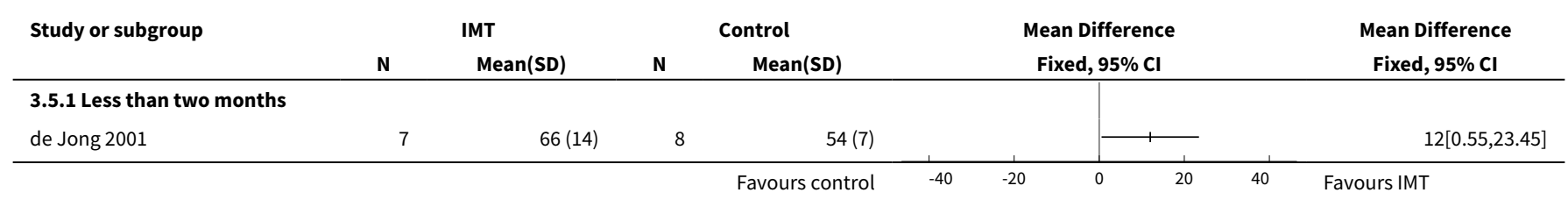


Comparison 4. RMT ( $20 \%$ of maximal effort) versus control

\begin{tabular}{lllll}
\hline Outcome or subgroup title & $\begin{array}{l}\text { No. of } \\
\text { studies }\end{array}$ & $\begin{array}{l}\text { No. of } \\
\text { partici- } \\
\text { pants }\end{array}$ & Statistical method & Effect size \\
\hline $\begin{array}{l}1 \text { Forced expiratory volume at one second } \\
\text { (L) }\end{array}$ & 1 & & $\begin{array}{l}\text { Mean Difference (IV, Fixed, 95\% } \\
\text { Cl) }\end{array}$ & Totals not selected \\
\hline 1.1 Two to six months & 1 & $\begin{array}{l}\text { Mean Difference (IV, Fixed, 95\% } \\
\text { Cl) }\end{array}$ & $0.0[0.0,0.0]$ \\
\hline 2 Forced vital capacity (L) & 1 & $\begin{array}{l}\text { Mean Difference (IV, Fixed, 95\% } \\
\text { Cl) }\end{array}$ & Totals not selected \\
\hline 2.1 Two to six months & 1 & $\begin{array}{l}\text { Mean Difference (IV, Fixed, 95\% } \\
\text { Cl) }\end{array}$ & $0.0[0.0,0.0]$ \\
\hline
\end{tabular}

Analysis 4.1. Comparison 4 RMT ( $20 \%$ of maximal effort) versus control, Outcome 1 Forced expiratory volume at one second (L).

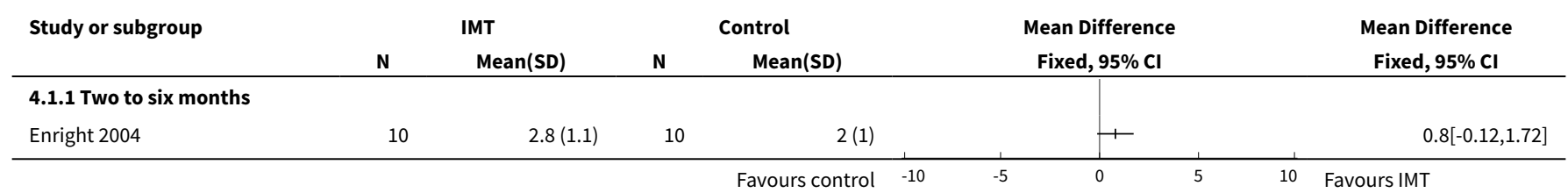

Analysis 4.2. Comparison 4 RMT ( $20 \%$ of maximal effort) versus control, Outcome 2 Forced vital capacity (L).

\begin{tabular}{|c|c|c|c|c|c|c|c|}
\hline \multirow[t]{2}{*}{ Study or subgroup } & \multicolumn{2}{|c|}{ IMT } & \multicolumn{2}{|c|}{ Control } & \multirow{2}{*}{\multicolumn{2}{|c|}{$\begin{array}{c}\text { Mean Difference } \\
\text { Fixed, } 95 \% \mathrm{Cl}\end{array}$}} & \multirow{2}{*}{$\begin{array}{c}\text { Mean Difference } \\
\text { Fixed, } 95 \% \mathrm{Cl} \\
\end{array}$} \\
\hline & $\mathbf{N}$ & Mean(SD) & $\mathbf{N}$ & Mean(SD) & & & \\
\hline \multicolumn{8}{|c|}{ 4.2.1 Two to six months } \\
\hline Enright 2004 & 10 & $3.8(1.2)$ & 10 & $2.9(1)$ & & 1 & $0.9[-0.07,1.87]$ \\
\hline
\end{tabular}

\section{AP PEN DICES}

\section{Appendix 1. Search strategy: clinicaltrials.gov}

\begin{tabular}{ll}
\hline Date of Search & $07 / 05 / 2018$ \\
\hline Years Covered & 1920 to $07 / 05 / 2018$ \\
\hline Complete Strategy & $\begin{array}{l}\text { 1. inspir*mus*train AND cystic fibrosis } \\
\text { 2. resp* }{ }^{*} \text { us }^{*} \text { train AND cystic fibrosis }\end{array}$
\end{tabular}




\section{Appendix 2. Search strategy: WHO ICTRP}

\begin{tabular}{ll}
\hline Date of Search & $07 / 05 / 2018$ \\
\hline Years Covered & 1920 to $07 / 05 / 2018$ \\
\hline Complete Strategy & 1. inspir*mus*train AND cystic fibrosis \\
& 2. resp* mus ${ }^{\star}$ train AND cystic fibrosis \\
& 3. press ${ }^{\star}$ thresh*load AND cystic fibrosis \\
\hline Language Restrictions & None \\
\hline
\end{tabular}

Appendix 3. Search strategy: MEDLINE, Embase, CINAHL, AMED, BIOSIS, EMB reviews (OVID-WEB)

\begin{tabular}{|c|c|}
\hline Date of Search & $01 / 08 / 2013$ \\
\hline Years Covered & 1966 to present \\
\hline Complete Strategy & $\begin{array}{l}\text { 1. randomised controlled trial.pt. } \\
\text { 2. controlled clinical trial.pt. } \\
\text { 3. randomised controlled trials.sh. } \\
\text { 4. random allocation.sh. } \\
\text { 5. double blind method.sh. } \\
\text { 6. single blind method.sh. } \\
\text { 7. or/1-6 } \\
\text { 8. (animals not human).sh. } \\
\text { 9. } 7 \text { not } 8 \\
\text { 10. clinical trial.pt. } \\
\text { 11. exp clinical trials/ } \\
\text { 12. (clin } \$ \text { adj25 trial\$).ti,ab. } \\
\text { 13. ((singl\$ or doubl\$ or trebl\$ or tripl\$) adj25 (blind\$ or mask\$)).ti,ab. } \\
\text { 14. placebos.sh. } \\
\text { 15. placebo } \$ . t i, \text { ab. } \\
\text { 16. random\$.ti,ab. } \\
\text { 17. research design.sh. } \\
\text { 18. or/10-17 } \\
\text { 19. } 18 \text { not } 8 \\
\text { 20. } 19 \text { not } 9 \\
\text { 21. comparative study.sh. } \\
\text { 22. exp evaluation studies/ } \\
\text { 23. follow up studies.sh. } \\
\text { 24. prospective studies.sh. } \\
\text { 25. (control\$ or prospectiv\$ or volunteer\$).ti,ab. } \\
\text { 26. or/21-25 } \\
\text { 27. } 26 \text { not } 8 \\
\text { 28. } 27 \text { not ( } 9 \text { or } 20)\end{array}$ \\
\hline
\end{tabular}




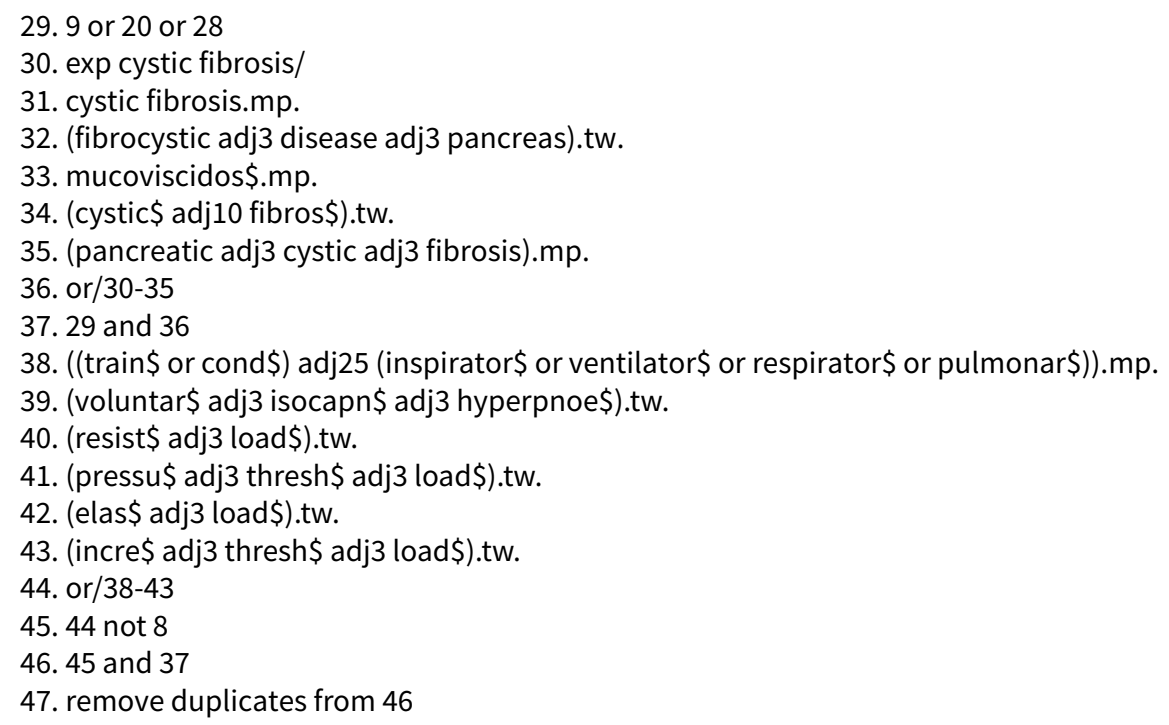

Summary of Strategy

Lines $1 \& 29$ are the Cochrane RCT filter.

Lines 30 to 37 are the Cochrane cystic fibrosis filter.

Lines 38 to 45 were to isolate the intervention of interest.

The remainder were to combine these three themes.

\section{Appendix 4. Search strategy: PEDro}

\begin{tabular}{|c|c|}
\hline Date of search & $01 / 08 / 2013$ \\
\hline Years covered & 1929 to present \\
\hline Complete strategy & $\begin{array}{l}\text { 1. inspir }{ }^{\star} \text { mus }^{\star} \text { train }^{\star} \\
\text { 2. resp* } \text { mus }^{\star} \text { train }^{\star} \\
\text { 3. resp } \text { mus }^{\star} \text { cond }^{\star} \\
\text { 4. resist } \text { load }^{\star} \\
\text { 5. press } \text { thresh }^{\star} \text { load }^{\star} \\
\text { 6. incre* thresh } \text { load }^{\star} \\
\text { 7. cystic fibrosis } \\
\text { 8. cyst }{ }^{\star} \text { fibro* } \\
\text { 9. pancreatic cystic fibrosis }\end{array}$ \\
\hline Summary of strategy & $\begin{array}{l}\text { PEDro is a database of controlled clinical trials, therefore no specific design oriented search terms. } \\
\text { All terms were geared to isolate the condition and the intervention. } \\
\text { The returned citations were then manually combined to be specific to the review question. }\end{array}$ \\
\hline Language restrictions & None \\
\hline
\end{tabular}

\section{Appendix 5. Search strategy: Science Direct}


Date of search

$01 / 08 / 2013$
1823 to present

1: (Title-Abstr-Key (random*)) OR (Title-Abstr-Key (placebo*)) OR (Title-Abstr-Key ((singl ${ }^{\star}$ or doubl* or trebl ${ }^{\star}$ or tripl $\left.{ }^{\star}\right)$ w/25 (blind ${ }^{\star}$ or mask $\left.\left.{ }^{*}\right)\right)$ OR (Title-Abstr-Key $\left(\right.$ clin $^{*}$ w/25 trial $\left.\left.{ }^{*}\right)\right)$

[All Sources(Medicine and Dentistry,Nursing and Health Professions)]

2: ((Title-Abstr-Key (random*)) OR (Title-Abstr-Key (placebo*)) OR (Title-Abstr-Key ((singl ${ }^{\star}$ or dou$\mathrm{bl}^{\star}$ or trebl* or tripl $\left.{ }^{\star}\right) \mathrm{w} / 25$ (blind ${ }^{*}$ or mask $\left.\left.{ }^{\star}\right)\right)$ ) OR (Title-Abstr-Key (clin* w/25 trial*))) OR ((Title-Abstr-Key (single blind method)) OR (Title-Abstr-Key (double blind method)) OR (Title-Abstr-Key (random allocation)) OR (Title-Abstr-Key (controlled clinical trial)) OR (Title-Abstr-Key (randomised controlled trial)))

[All Sources(Medicine and Dentistry,Nursing and Health Professions)]

3: Title-Abstr-Key (cystic fibrosis)

[All Sources(Medicine and Dentistry,Nursing and Health Professions)]

4: Title-Abstr-Key (fibrocystic $w / 3$ disease $w / 3$ pancreas)

[All Sources(Medicine and Dentistry,Nursing and Health Professions)]

5: Title-Abstr-Key (mucoviscidos ${ }^{\star}$ )

[All Sources(Medicine and Dentistry,Nursing and Health Professions)]

6: Title-Abstr-Key (cystic ${ }^{\star}$ w/10 fibros ${ }^{\star}$ )

[All Sources(Medicine and Dentistry,Nursing and Health Professions)]

7: Title-Abstr-Key (pancreatic w/3 cystic w/3 fibrosis)

[All Sources(Medicine and Dentistry,Nursing and Health Professions)]

8: (Title-Abstr-Key (pancreatic w/3 cystic w/3 fibrosis)) OR (Title-Abstr-Key (cystic* w/10 fibros $\left.{ }^{\star}\right)$ )

OR (Title-Abstr-Key (mucoviscidos $\left.{ }^{\star}\right)$ ) OR (Title-Abstr-Key (fibrocystic w/3 disease w/3 pancreas)) OR (Title-Abstr-Key (cystic fibrosis))

[All Sources(Medicine and Dentistry,Nursing and Health Professions)]

9: Title-Abstr-Key (train* or cond ${ }^{\star}$ ) w/3 (inspirator ${ }^{\star}$ or ventilator ${ }^{\star}$ or respirator ${ }^{\star}$ or pulmonar ${ }^{\star}$ )

[All Sources(Medicine and Dentistry,Nursing and Health Professions)]

10: Title-Abstr-Key (resist* ${ }^{\star}$ w/3 load ${ }^{\star}$ )

[All Sources(Medicine and Dentistry,Nursing and Health Professions)]

11: Title-Abstr-Key (inspiratory muscle training)

[All Sources(Medicine and Dentistry,Nursing and Health Professions)]

12: (Title-Abstr-Key (inspiratory muscle training)) OR (Title-Abstr-Key (resist* w/3 load $\left.{ }^{\star}\right)$ ) OR (Title-Abstr-Key (train* or cond ${ }^{\star}$ ) w/3 (inspirator ${ }^{*}$ or ventilator ${ }^{\star}$ or respirator* or pulmonar $\left.{ }^{\star}\right)$ )

[All Sources(Medicine and Dentistry,Nursing and Health Professions)]

13: (Title-Abstr-Key (inspiratory muscle training)) OR (Title-Abstr-Key (resist* w/3 load*)) OR (Title-Abstr-Key (train* or cond ${ }^{\star}$ ) w/3 (inspirator ${ }^{\star}$ or ventilator ${ }^{\star}$ or respirator ${ }^{\star}$ or pulmonar $^{\star}$ ))

[All Sources(Medicine and Dentistry,Nursing and Health Professions)]

14: ((Title-Abstr-Key (inspiratory muscle training)) OR (Title-Abstr-Key (resist* w/3 load $\left.{ }^{\star}\right)$ ) OR (Title-Abstr-Key (train* or cond $\left.{ }^{\star}\right) \mathrm{w} / 3$ (inspirator ${ }^{\star}$ or ventilator ${ }^{\star}$ or respirator ${ }^{\star}$ or pulmonar $\left.\left.{ }^{\star}\right)\right)$ ) AND ((Title-Abstr-Key (pancreatic w/3 cystic w/3 fibrosis)) OR (Title-Abstr-Key (cystic ${ }^{\star}$ w/10 fibros $\left.{ }^{\star}\right)$ ) OR (Title-Abstr-Key (mucoviscidos*)) OR (Title-Abstr-Key (fibrocystic w/3 disease w/3 pancreas)) OR (Title-Abstr-Key (cystic fibrosis))) AND (((Title-Abstr-Key (random*)) OR (Title-Abstr-Key (placebo*)) OR (Title-Abstr-Key $\left(\left(\right.\right.$ singl $^{*}$ or doubl ${ }^{*}$ or trebl* or tripl $\left.{ }^{\star}\right)$ w/25 (blind ${ }^{\star}$ or mask $\left.\left.{ }^{\star}\right)\right)$ ) OR (Title-Abstr-Key $\left(\right.$ clin $^{\star}$ w/25 trial $\left.\left.\left.{ }^{\star}\right)\right)\right)$ OR ((Title-Abstr-Key (single blind method)) OR (Title-Abstr-Key (double blind method)) OR (Title-Abstr-Key (random allocation)) OR (Title-Abstr-Key (controlled clinical trial)) OR (Title-Abstr-Key (randomised controlled trial))))

[All Sources(Medicine and Dentistry,Nursing and Health Professions)]

15: ((Title-Abstr-Key (pancreatic w/3 cystic w/3 fibrosis)) OR (Title-Abstr-Key (cystic* w/10 fibros*)) OR (Title-Abstr-Key (mucoviscidos*)) OR (Title-Abstr-Key (fibrocystic w/3 disease w/3 pancreas)) OR (Title-Abstr-Key (cystic fibrosis))) AND (((Title-Abstr-Key (random*)) OR (Title-Abstr-Key (placebo*)) OR (Title-Abstr-Key ((singl ${ }^{*}$ or doubl* or trebl* or tripl*) w/25 (blind ${ }^{*}$ or mask* $\left.\left.{ }^{\star}\right)\right)$ OR (Title-Abstr-Key (clin* w/25 trial*))) OR ((Title-Abstr-Key (single blind method)) OR (Title-Abstr-Key (double blind method)) OR (Title-Abstr-Key (random allocation)) OR (Title-Abstr-Key (controlled clinical trial)) OR (Title-Abstr-Key (randomised controlled trial))))

[All Sources(Medicine and Dentistry,Nursing and Health Professions)]

16: ((Title-Abstr-Key (inspiratory muscle training)) OR (Title-Abstr-Key (resist* w/3 load $\left.{ }^{\star}\right)$ ) OR (Title-Abstr-Key (train* or cond $\left.{ }^{\star}\right) \mathrm{w} / 3$ (inspirator ${ }^{\star}$ or ventilator ${ }^{\star}$ or respirator ${ }^{\star}$ or pulmonar $\left.\left.{ }^{\star}\right)\right)$ ) AND ((Title-Abstr-Key (pancreatic w/3 cystic w/3 fibrosis)) OR (Title-Abstr-Key (cystic ${ }^{\star}$ w/10 fibros $\left.{ }^{\star}\right)$ ) OR 
[All Sources(Medicine and Dentistry,Nursing and Health Professions)]

Summary of strategy

Lines $1 \& 2$ were to isolate studies of appropriate design.

Lines 3 to 8 were to isolate the condition of interest.

Lines 9 to 13 were to isolate the intervention of interest.

The remainder were to combine these three themes.

\begin{tabular}{ll}
\hline Language restrictions None \\
\hline
\end{tabular}

Appendix 6. Search strategy: SCOPUS

\begin{tabular}{|c|c|}
\hline Date of search & $01 / 08 / 2013$ \\
\hline Years covered & 1966 to present \\
\hline Complete strategy & 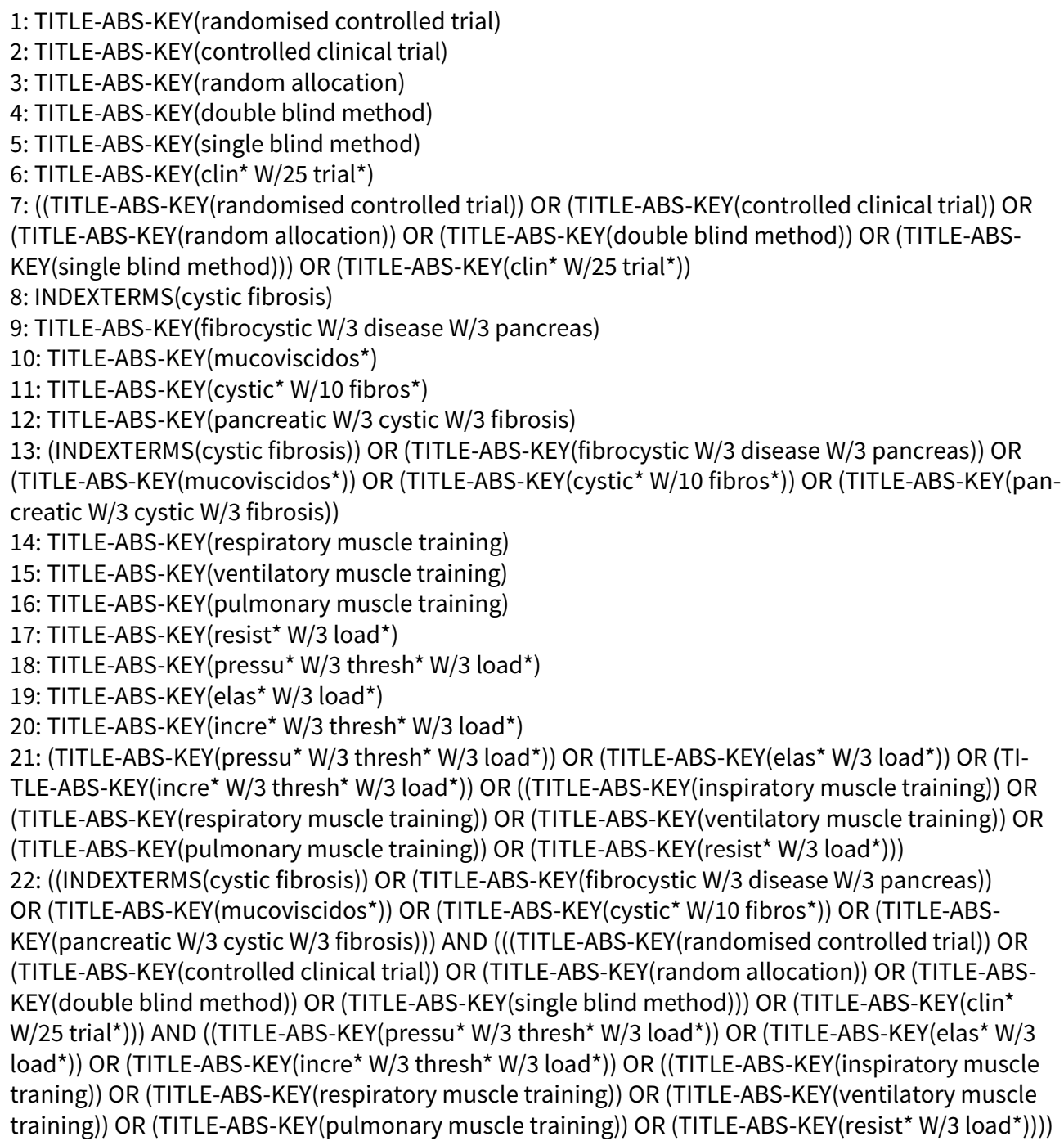 \\
\hline
\end{tabular}


(Continued)

Lines 8 to 13 were to isolate the condition.

Lines 14 to 21 were to isolate the intervention.

Line 22: Combines these three themes.

None

Appendix 7. Search strategy: MEDLINE, CINHAL and AMED (EBSCOHost)

\begin{tabular}{|c|c|}
\hline Date of search & $01 / 08 / 2013$ \\
\hline Years covered & 1966 to present \\
\hline Complete strategy & 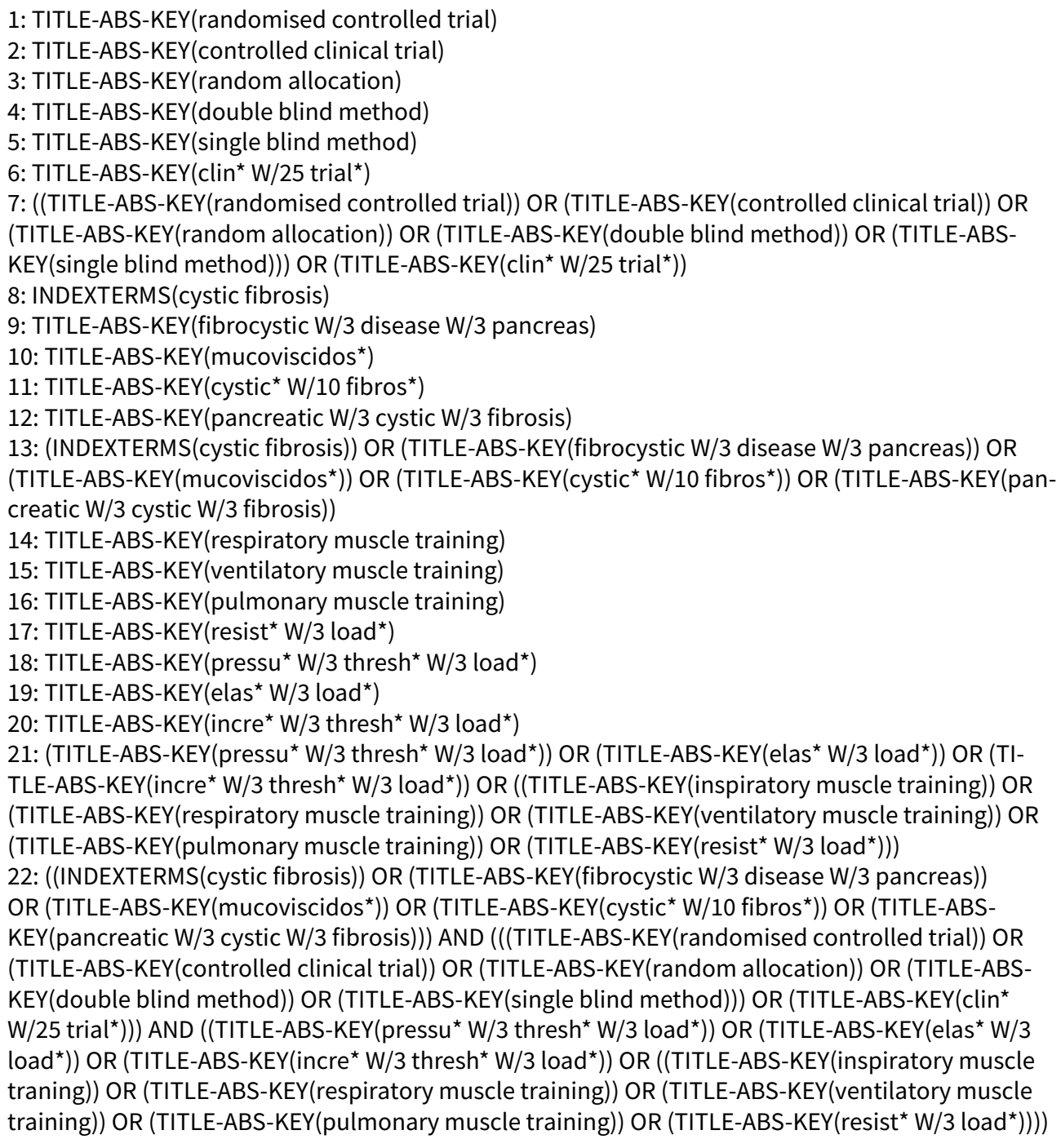 \\
\hline Summary of strategy & $\begin{array}{l}\text { Lines } 1 \text { to } 7 \text { were to isolate appropriate study design. } \\
\text { Lines } 8 \text { to } 13 \text { were to isolate the condition. } \\
\text { Lines } 14 \text { to } 21 \text { were to isolate the intervention. } \\
\text { Line 22: Combines these three themes. }\end{array}$ \\
\hline
\end{tabular}


WHAT'S NEW

\begin{tabular}{lll}
\hline Date & Event & Description \\
\hline 21 May 2018 & New search has been performed & $\begin{array}{l}\text { A search of the Cochrane Cystic Fibrosis and Genetic Disorders } \\
\text { Review Group's Cystic Fibrosis Trials Register identified five ref- } \\
\text { erences potentially eligible for inclusion in the review. One was } \\
\text { an additional reference to an already included study (Amelina }\end{array}$ \\
& $\begin{array}{l}\text { 2006). One study was eligible for inclusion (Bieli 2017), where- } \\
\text { as three studies were excluded (Giacomodonato 2015; Ozaydin } \\
\text { 2010; Patterson 2004). }\end{array}$
\end{tabular}

Evaluation of the quality of the evidence has been undertaken using GRADE and the results presented in a summary of findings table.

21 May $2018 \quad$ New citation required but conclusions have not changed
The title of the review has been changed from 'Inspiratory muscle training for cystic fibrosis' to 'Respiratory muscle training for cystic fibrosis'.

The review team has changed as the lead author (Brian Houston) and one co-author (Nicola Mills) have stepped down. The new lead author is Nathan Hilton.

Despite the inclusion of one additional study at this update, the review's conclusions remain the same.

\section{HISTOR Y}

Protocol first published: Issue 3, 2006

Review first published: Issue 4, 2008

\begin{tabular}{lll}
\hline Date & Event & Description \\
\hline 10 October 2013 & $\begin{array}{l}\text { New citation required but conclusions } \\
\text { have not changed }\end{array}$ & $\begin{array}{l}\text { No new studies have been included in this update of the review } \\
\text { and our conclusions have remained the same. }\end{array}$ \\
\hline
\end{tabular}

10 October $2013 \quad$ New search has been performed

A search of the Cystic Fibrosis \& Genetic Disorders Group's Cystic Fibrosis Register identified two references to a single study that was potentially eligible for inclusion in the review; this study has been excluded (Irons 2012). Searches of MEDLINE, CIHNAL, AMED and SCOPUS identified two additional studies that were potentially eligible for inclusion in the review, but both of these were also excluded (Santana-Sosa 2013; Vivodtzev 2013).

28 September $2011 \quad$ New search has been performed

A search of the Cystic Fibrosis Trials Register identified three new references which were potentially eligible for inclusion in this review (Amelina 2006; Chatham 1997; Howard 2000). Two studies were eligible for inclusion (Amelina 2006; Chatham 1997); the third study was excluded (Howard 2000). 


\begin{tabular}{lll}
\hline Date & Event & Description \\
\hline & & $\begin{array}{l}\text { Additional searching undertaken for the updated review identi- } \\
\text { fied one study that was potentially eligible for inclusion (Sartori } \\
2008) ; \text { however this was excluded on closer examination. }\end{array}$ \\
\hline Ampril 2008 & Amended & Converted to new review format. \\
\hline
\end{tabular}

\section{CONTRIBUTIONS OF AUTHORS}

\section{Up to 2018}

Brian Houston drafted the protocol with comments from Helen Handoll and Cees van der Schans.

Nicola Mills, Arturo Solis-Moya and Brian Houston extracted data and assessed study quality. Brian Houston drafted the full review with comments from Nicola Mills and Arturo Solis-Moya.

Brian Houston acts as guarantor of the review.

\section{From 2018}

Nathan Hilton drafted the update with comments from Arturo Solis-Moya.

Nathan Hilton and Arturo Solis-Moya extracted data and assessed study quality.

\section{DECLARATIONS OF INTEREST}

None known.

\section{SOURCES OF SUPPORT}

\section{Internal sources}

- No sources of support supplied

\section{External sources}

- National Institute for Health Research, UK.

This systematic review was supported by the National Institute for Health Research, via Cochrane Infrastructure funding to the Cochrane Cystic Fibrosis and Genetic Disorders Group.

\section{DIFFERENCES BETWEEN PROTOCOLANDREVIEW}

\section{Update 2011}

Due to Teesside University (location of the lead author) changing its search engine, some of the search strategies have been re-written. The search strategies in Appendix 5 have superseded those in Appendix 1.

\section{Update 2018}

In line with current Cochrane guidance, summary of findings tables have been added. The title has been changed from 'Inspiratory muscle training for cystic fibrosis' to 'Respiratory muscle training for cystic fibrosis'.

The new author team has re-ordered the outcomes to prioritise outcomes that are deemed more clinically meaningful to people with CF.

\section{IN DEX TERMS}

\section{Medical Subject Headings (MeSH)}

*Breathing Exercises; Cystic Fibrosis ["therapy]; Inhalation [ ${ }^{\star}$ physiology]; Randomized Controlled Trials as Topic; Respiratory Muscles [ ${ }^{\star}$ physiology]

\section{MeSH check words}

Adult; Child; Humans 